\title{
EXISTE SOLUÇÃO JUSTA PARA O CASO DO JARDIM BOTÂNICO DO RIO DE JANEIRO?
}

\author{
Armando Miranda Filho
}

IS THERE ANY JUST SOLUTION FOR THE CASE OF BOTANICAL GARDEN OF RIO DE JANEIRO?

\section{RESUMO}

O OBJETIVO DESTE ARTIGO RESIDE NA ANÁLISE DO CASO DO JARDIM BotÂNICO DA CIDADE DO RIO DE JANEIRO, ONDE, AO LONGO DO TEMPO, SE INSTALOU A COMUNIDADE DO HORTO, POR MEIO DE OCUPACÕ̃ES CONSOLIDADAS EM ÁREA DA UNIÃO FEDERAL. A QUESTÃO ENCONTRA-SE JUDICIALIZADA E A PARTIR DE PROCESSOS INICIADOS NOS ANOS 1980 (NOS QUAIS A PRÓPRIA UNIĀO É PARTE AUTORA) QUE VISARAM À RETIRADA DOS MORADORES. LEVAREMOS EM CONTA QUE A POLÍTICA DE GESTÃO DE IMÓVEIS DA UNIÃO TEM PASSADO, NESSE PERÍODO, POR UM PROCESSO CONTÍNUO E GRADATIVO DE MUDANÇA DE VISÃO, COM PARTICULAR REFERÊNCIA ÀS ÁREAS QUE POSSUEM OCUPACÕES CONSOLIDADAS, COM MORADIAS INSTALADAS. A COMPLEXIDADE DAS RELAÇÕES ENTRE OS MAIS DIVERSOS ATORES INSTITUCIONAIS ENVOLVIDOS PERMITE UMA ABORDAGEM VOLTADA PARA A PERCEPÇÃO, NO CAMPO DA REALIDADE, DE COMO O DIREITO À MORADIA DEVE (OU PODE) SE MATERIALIZAR FRENTE À COMPREENSĀO DE ARGUMENTOS TRADICIONAIS DO DIREITO. A INVESTIGACÃ̃O PRESSUPÕE A ANÁLISE DE PROCESSO ADMINISTRATIVO INSTRUÍDO NO ÂMBITO DA CÂMARA DE CONCILIAÇÃO e Arbitragem da Administração Pública Federal, utilizandoSE OS MÉTODOS HISTÓRICO-COMPARATIVO, CONCEITUAL-DEDUTIVO E EMPÍRICO-INDUTIVO. TRATAREMOS DE DEMONSTRAR A VALIDADE DA TEORIA POLÍTICA DESENVOLVIDA PELA CRÍTICA COMUNITARISTA NORTE-AMERICANA E SUA ESPECIAL CONTRIBUIC̄̃O PARA AS NOÇÕES DE JUSTIÇA SEGUNDO A CONCEPÇÃO CONTEMPORÂNEA. CONTEXTUALIZAREMOS O PROBLEMA CONCRETO ENFRENTADO PELA COMUNIDADE dO HORTO, SEU HISTÓRICO, E ESBOÇAREMOS O PERFIL DA COMUNIDADE, A PARTIR DA EXPOSIC̣ÃO DE DADOS SOCIOECONÔMICOS DAS PESSOAS QUE HABITAM O LOCAL. EXAMINAREMOS AS POLITIICAS PÚBLICAS DE GESTĀO DOS IMÓVEIS DA UnIÃO, DESTACANDO O PAPEL DA SECRETARIA DO PATRIMÔNIO DA UNIÃO E AS MUDANÇAS PARADIGMÁTICAS DESSA GESTÃO, SENSIVELMENTE PERCEBIDAS NAS ÚLTIMAS DUAS DÉCADAS. PASSAREMOS EM REVISTA A ARGUMENTAÇÃO DELINEADA EM UMA AC̣ÃO JUDICIAL POSSESSÓRIA INDIVIDUAL - O CASO GRACINDA - QUE DEU ORIGEM A UMA AUdITORIA REALIZADA PELO TRIBUNAL DE

\section{ABSTRACT}

THE PURPOSE OF THIS ARTICLE IS THE ANALYSIS OF THE CASE of THE Botanical GARDEN IN RIO DE JANEIRO, WHERE, OVER TIME, SETTLED AT THE COMMUNITY OF HORTO, THROUGH OCCUPATIONS CONSOLIDATED IN THE AREA OF THE FEDERAL GOVERNMENT. THE QUESTION IS PROSECUTED AND FROM CASES INITIATED IN THE 1980S (IN WHICH THE UNION ITSELF IS THE PLAINTIFF) WHO SOUGHT THE WITHDRAWAL OF THE RESIDENTS. IT WILL TAKE INTO ACCOUNT THAT THE MANAGEMENT POLICY OF BRAZILIAN GOVERNMENT HAS SPENT PROPERTIES IN THIS PERIOD, FOR A CONTINUOUS AND GRADUAL CHANGE OF VISION, WITH PARTICULAR REFERENCE TO AREAS THAT HAVE OCCUPATIONS CONSOLIDATED WITH HOUSING INSTALLED. THE COMPLEXITY OF THE RELATIONSHIPS AMONG THE VARIOUS INSTITUTIONAL ACTORS ENABLES A FOCUSED APPROACH TO THE PERCEPTION IN THE FIELD OF REALITY, SUCH AS THE RIGHT TO HOUSING SHOULD (OR CAN) MATERIALIZE AGAINST THE TRADITIONAL UNDERSTANDING OF LAWS. THE RESEARCH INVOLVES THE ANALYSIS OF ADMINISTRATIVE PROCEEDINGS INSTRUCTED WITHIN THE CHAMBER of CONCILIATION OF THE FEDERAL PUBLIO ADMINISTRATION, USING THE HISTORICAL-COMPARATIVE, CONCEPTUAL-DEDUCTIVE AND EMPIRICAL-INDUCTIVE METHODS. WE WILL DEMONSTRATE THE VALIDITY OF POLITICAL THEORY DEVELOPED BY AMERICAN COMMUNITARIAN CRITIQUE AND ITS SPECIAL CONTRIBUTION TO THE NOTIONS OF JUSTICE IN CONTEMPORARY DESIGN. WE WILL CONTEXTUALIZE THE SPECIFIC PROBLEM FACED BY THE COMMUNITY OF HORTO, ITS HISTORY AND OUTLINE THE PROFILE OF THAT COMMUNITY, FROM THE EXPOSURE OF SOCIO-ECONOMIC DATA OF THE PEOPLE WHO INHABIT THE PLACE. WE WILL EXAMINE THE PUBLIC POLICY OF MANAGING PROPERTIES OF FEDERAL GOVERNMENT, HIGHLIGHTING THE ROLE OF SPU ASSETS AND PARADIGMATIC CHANGES THAT MANAGEMENT PERCEIVED SIGNIFICANTLY IN THE LAST TWO DECADES. WE WILL REVIEW THE ARGUMENTS OUTLINED IN A LAWSUIT POSSESSORY 
CONTAS DA UNIÃO, QUE CULMINOU EM DECISÃO PROFERIDA PELA CoRTE DE ContAS, EM SETEMBRo de 2012, A QUAL TAMBÉM SERÁ OBJETO DE NOSSA ANÁlise. SitUA-SE O TEMA, PORTANTO, NO CAMPO DA EFETIVIDADE DOS DIREITOS, ENTRE A NORMA JURÍDICA E O FATO SOCIAL.

PALAVRAS-CHAVE

Políticas públicas; Politologia; Comunidade do Horto; JARDIM BOTÂNICO DO RIO DE JANEIRO.
INDIVIDUAL - THE GRACINDA CASE - WHICH LED TO AN AUDIT BY THE COURT OF AUDIT, WHICH CULMINATED IN A DECISION RENDERED IN SEPTEMBER 2012, WHICH WILL ALSO BE OBJECT OF OUR ANALYSIS. LIES THE THEME, SO, BETWEEN THE RULE OF LAW AND THE SOCIAL FACT.

\section{KEYWORDS}

Public POLICIES; Politology; LAND CONFlicts; The COMmunity of "Horto"; Botanical Garden of Rio de Janeiro.

\section{INTRODUÇÃO}

$\mathrm{Na}$ pesquisa que desenvolvemos atualmente no curso de mestrado na linha Direito e Políticas Públicas, ${ }^{1}$ investigamos o problema relativo à Comunidade do Horto, na cidade do Rio de Janeiro, que é formada por moradias situadas dentro dos limites de propriedade da União Federal onde também fica o Jardim Botânico do Rio de Janeiro. O problema é antigo (como se demonstrará) e são frequentes os discursos e as ações políticas ora em prol da retirada, ora pela manutenção dos moradores no local. A questão encontra-se submetida à esfera de várias instituições públicas, dos três poderes, especialmente no plano federal.

Lida-se, neste caso, como adiante contextualizaremos o leitor, com múltiplos interesses políticos e inúmeros problemas no campo da realidade social. Todos os atores envolvidos, direta ou indiretamente, clamam por um desfecho justo. Nos últimos trinta anos, contudo, o poder público encontrou dificuldades para encontrar soluções. E mais: nessa busca, tomou posturas e adotou discursos e ações muitas vezes contraditórios em torno da melhor solução para o caso, em outras palavras, em torno da solução mais justa.

Para o bom andamento da investigação que desenvolvemos em nossa pesquisa em que diversas noções de justiça orientam uma pluralidade de argumentos para a adoção de uma ou outra solução, fomos atraídos pela importância do debate entre comunitaristas e utilitaristas, os seus desdobramentos, e a influência da crítica comunitarista ao direito. ${ }^{2}$ Nessa linha, a lição de diversos expoentes da filosofia e teoria política norte-americana que influenciam o pensamento atual, tais como Rawls, MacIntyre, Walzer, Sandel, Taylor e Selznick, servem de norte teórico para a investigação que se pretende aqui realizar.

Para a nossa pesquisa interessam-nos tanto a atuação de tribunais judiciais quanto as tentativas administrativas no enfrentamento do problema; aliás a interlocução dos discursos entre um e outro torna particularmente interessante a identificação das práticas adotadas por essas instituições, bem como dos argumentos por elas lançados nos momentos decisórios. E disso decorre uma crucial indagação: em que medida as instituições podem servir à resolução justa das complexas questões que se lhes impõem?

Cabe-nos, pois, indagar se seria possível, a partir da análise desse complexo caso brasileiro, que envolve todas essas multiplicidades de interesses políticos bem como 
a atuação tanto de cidadãos quanto de instituições públicas e privadas, inclusive tribunais, identificar esses contornos de justiça na tentativa de se buscar solução de problema social concreto.

Nossa hipótese é que, havendo discordância nos discursos políticos utilizados para sustentar cada dada proposta de melhor solução para o caso - e estando tais discursos fundados em concepções eminentemente emotivistas, ${ }^{3}$ que encontram respaldo em um ou mais grupos sociais e na própria lei -, as instituições públicas não dispõem de instrumentos efetivos para resolver problemas sociais complexos, o que gera incoerência em suas ações e, por conseguinte, descrença da sociedade quanto à legitimidade de suas decisões para a entrega da justiça.

Nesse passo, devemos assentar que o debate na teoria política norte-americana entre utilitaristas e comunitaristas - e a especial contribuição da última corrente em torno das concepções morais da noção de justiça -, definitivamente marcado nos anos 1980, depois de uma década da publicação de Uma teoria da justiça, em 1971, ${ }^{4}$ de John Rawls, certamente possui implicações diretas nas discussões do Direito, inclusive no Brasil, ainda mais quando se voltam os olhos para a prática das instituições brasileiras que têm a função de decidir.

Nesse exercício, dissecando o que já dissemos nessas primeiras linhas, ora encontraremos o discurso que preconiza a retirada de todas as moradias da Comunidade, em nome da preservação ambiental, da expansão da pesquisa botânica ou da defesa dos aspectos histórico-culturais imanentes ao local, ora aquele que sustenta o direito de permanência (ou, no mínimo, de realocação) dos moradores do local, dados os aspectos subjetivos das ligações entre o homem, sua moradia e a comunidade em que vive, além dos aspectos objetivos quanto ao tempo das habitações e a faixa de renda das famílias, invocando-se o direito à moradia reconhecido e protegido pelas leis.

Desde já devemos assentar que esses discursos se contrapõem e se conflitam de forma intensa especialmente nas últimas três décadas, e as perspectivas para a resolução efetiva do problema concreto somente diminuem. Pretendemos, assim, em nossa pesquisa, desenvolver um exercício de politologia que identifique a interlocução, no caso concreto, entre o político e o jurídico. Situa-se o nosso artigo, portanto, no campo da efetividade de direitos, entre a norma jurídica e o fato social.

Deve-se aqui apor que essa linha de pensamento pressupõe a existência de uma crise do direito com a exaustão de um paradigma juspositivista, ${ }^{5}$ transformação verificada no Brasil - e nos países do ocidente - pelo menos nas últimas quatro décadas, depois de longos anos da dominação do discurso voltado para a insistente busca pela generalização do fenômeno social através da ciência jurídica, onipresente no discurso jurídico dos séculos 18, 19, e na maior parte do século 20.

Não se olvide que o positivismo jurídico é ainda hoje fortemente presente na teoria e na prática do direito. Os seus princípios, conceitos e métodos continuam 
influenciando o ensino jurídico nas universidades e o cotidiano das atividades forenses em todo o mundo ocidental, não obstante as diversas teorias críticas desenvolvidas principalmente a partir da segunda metade do século passado. ${ }^{6} \mathrm{O}$ modelo exposto por Freitas Filho, na linha dos ensinamentos de Faria, ${ }^{7}$ no que ele denomina de crise de um paradigma ${ }^{8}$ no direito é essencial para situarmos a linha de nossas ideias:

Há, portanto, momentos em que os paradigmas entram em crise. Isto ocorre quando eles não conseguem mais fornecer orientações, diretrizes e normas capazes de nortear o trabalho científico. Os problemas deixam de ser resolvidos conforme as regras vigentes - para cada problema solucionado vão surgindo outros de maior complexidade. A certa altura, o efeito cumulativo deste processo entra num período de crise: não tendo mais condições de fornecer soluções, os paradigmas vigentes começam a revelar-se como fonte última dos problemas e das incongruências, e o universo científico que lhes corresponde gradativamente converte-se num amplo sistema de erros, onde nada pode ser pensado corretamente. A partir daí, outros paradigmas emergem no horizonte cientifico - e o processo em que eles aparecem e se consolidam constitui o que Kuhn chama de revolução científica.

O Direito em sua matriz juspositivista kelseniana vem sendo discutido não é de agora, e trabalhos das mais diversas áreas das ciências humanas apontam para as condições de mudança e complexidade na realidade social.

(FREITAS FILHO, p. 37-38).

Também de se registrar que essa crise do direito, como bem destaca o primeiro capítulo da dissertação de mestrado que ensejou a obra de Freitas Filho, se dá em três diferentes níveis: o normativo, o institucional e o jurídico-cultural. Especialmente interessante para nós que as instituições jurídicas brasileiras revelamse, diante de casos complexos, notadamente aqueles que envolvem multi-interesses e cujo problema esteja judicializado, não disporem de instrumentos ou mecanismos de que possam lançar mão para enfrentar com eficiência essas questões multilaterais, que demandam cada vez mais comumente respostas concretas e céleres por parte do welfare state.

Nesse passo, quando os interesses são complexos e multifacetados (ambos moral e legalmente sustentáveis) a conformação do interesse público (tão caro ao direito administrativo) acaba representando não uma definição jurídica precisa do instituto que corresponderia a uma realidade direta e univocamente definível, mas um jogo de forças dentro do tabuleiro sociopolítico ${ }^{9}$ cujo resultado é não outro que a instabilidade do discurso e, com o tempo, a própria descrença nas instituições.

Por falarmos em interesse público, é preciso registrar que no contexto dos dois últimos séculos, ${ }^{10}$ realiza-se, na administração pública ocidental, uma espécie 
de homogeneização dos interesses, o que pressupõe a concepção de sociedades homogêneas, tendendo-se para a redução dos interesses das pessoas - ainda que profundamente complexos, diversos e difusos entre si - em um denominador comum. O mesmo raciocínio vale para as comunidades. Giannini, citado por Medauar (2003) denominou de publicização potencial de todo interesse tendo alguma relevância social. ${ }^{11}$ Assim qualquer assunto, desde que assumido pelo poder público, passa a se qualificar como questão de interesse público.

A prática, no entanto, nem sempre se realiza conforme a teoria. E na atuação do Estado, o quadro acima se reflete na burocracia da administração pública: o emaranhado de normas jurídicas (leis, portarias, regulamentos), a diluição de competências no exercício das funções públicas entre diversos órgãos, as práticas isoladas de cada órgão público, dentre outros fatores, levam a uma atuação desconexa por parte do poder público, que, no fundo, apenas catalisa e reproduz essa multilateralidade de interesses da comunidade nos diversos campos de atuação do Estado.

Essa desconexão é mais ainda sentida quando se voltam os olhos para a atuação prática de instituições públicas que se envolvem numa dada demanda socialmente complexa. Não raro essas questões são levadas ao Judiciário ou aos órgãos de controle - e as decisões do Estado refletem exatamente o tal jogo de forças e interesses, desprovido de mecanismos eficientes para apresentar soluções. Assim, em casos como o do Jardim Botânico do Rio de Janeiro qualquer intervenção estatal pode ter consequências dramáticas a partir do aniquilamento de alguns dos interesses envolvidos e da prevalência de outros, sem que haja uma apreciação profunda dos complexos fatores que permeiam o caso.

Por oportuno, devemos esclarecer que a metodologia empregada reside na análise de um processo de natureza administrativa, em que se pode dessumir a multiplicidade dos interesses políticos envolvidos e dos discursos jurídicos desenvolvidos em torno da questão relativa às ocupações consolidadas nos arredores do Jardim, processo este impulsionado dentro da estrutura organizacional da União - o qual contém elementos importantíssimos para a nossa pesquisa empírica. Ari Sundfeld (2008), ${ }^{12}$ proeminente professor brasileiro de Direito Administrativo, faz a seguinte reflexão: "os males do excesso (a principiologia frouxa desamarrando as normas, embaralhando tudo) e do superficial (o princípio lugar-comum, pura forma sem substância); nisso vivemos”. E mais:

não é questão de conhecer a substância, o núcleo duro, expresso em institutos ou princípios (ou outras variáveis com essa função). O modelo é outro. Mentalizo o direito administrativo como um oceano: grandes águas, vagas, marés; eterno balanço e rodopio. Conhecê-lo é entender as constantes de seu movimento, dos fluxos e refluxos, enfim, dos contrários batendo-se e convivendo. Teoria dos antagonismos é o nome 
dessa matriz de análise, que foca no jogo de oposições a circundar as leis, as regras, as práticas, os casos, as decisões, os princípios, os institutos. (...) Essa teoria não crê na solução dos casos pela incidência direta de elementos fixos; ela não renega os institutos nem os princípios. A lei constrói figuras, a doutrina as tenta classificar e definir, o operador as testa ao decidir; eis os institutos, um modo inevitável do direito como norma, teoria e prática. Mas há de vê-los como institutos flexíveis, compatíveis com o inclassificável, o experimentalismo responsável, a acomodação dos contrários.

Nessa linha, o processo administrativo n. 00405.008207/2010-50, que tramita na Câmara de Conciliação e Arbitragem da Administração Pública Federal (CCAF), ${ }^{13}$ órgão da Advocacia-Geral da União, reúne documentos, dados, estatísticas, relatórios, memorandos, ofícios e outros expedientes técnicos gestados no poder executivo, assim como petições de moradores, do Ministério Público, além de decisões judiciais de diversas instâncias e do Tribunal de Contas da União, que abordaram a questão ao longo do tempo. Enfim, trata-se de um vasto material bruto que nos permite extrair do caso concreto os aspectos generalizáveis das argumentações delineadas pelos mais diversos atores em torno dos interesses que permeiam a questão.

Este texto, no entanto, dadas as limitações naturais de espaço, encontra-se seccionado em cinco partes, além desta introdução.

Em primeiro lugar, (1) trataremos de superar as resistências em torno das lições de Rawls e demonstrar a validade da teoria política desenvolvida pela crítica comunitarista norte-americana que o sucedeu e sua especial contribuição para as noções de justiça em sua concepção contemporânea. Em seguida, (2) contextualizaremos o problema concreto enfrentado pela Comunidade do Horto, seu histórico e esboçaremos o perfil da comunidade, a partir da exposição de dados scioeconômicos das pessoas que habitam o local, obtidos por meio de estudo desenvolvido pela Universidade Federal do Rio de Janeiro. ${ }^{14}$ Depois, (3) examinaremos as políticas públicas de gestão dos imóveis da União, destacando o papel da Secretaria do Patrimônio da União e as mudanças paradigmáticas dessa gestão, sensivelmente percebidas nas últimas duas décadas, com o apoio em leis e ações estatais nitidamente comunitaristas. Passo seguinte, (4) passaremos em revista, a partir de uma análise crítica, a argumentação delineada em uma ação judicial possessória individual - o caso Gracinda - que deu origem a uma auditoria realizada pelo Tribunal de Contas da União, que acabou culminando em decisão proferida pela Corte de Contas, em setembro de 2012, decisão essa que tratou do problema da Comunidade do Hor to como um todo, cujo relatório de levantamento e votos condutores também serão objeto de nossos comentários. Por fim, aporemos nossas conclusões sobre a questão. 


\section{SUPERANDO RESISTÊNCIAS}

Saliente-se, desde logo, que a pretensão de Rawls de fundar, na justiça, uma estrutura básica da sociedade compreendida pela distribuição de direitos e deveres fundamentais e das vantagens resultantes da cooperação social pelas instituições mais importantes, sejam elas políticas, econômicas ou sociais (RAWLS, ob. cit, p. 7-8) e as pertinentes pontuações comunitaristas que se seguiram, embora resultado de uma longa tradição do pensamento liberal norte-americano, tiveram impactos significativos na teoria política por todo o globo, mormente nos países da common law. Todavia, parecem não ter encontrado no debate brasileiro a merecida reverberação.

Para a nossa surpresa, as diferenças entre as sociedades e tradições brasileiras e americanas não constituíram o propagado (posto que falso) empecilho para que encontrássemos elementos cruciais na teoria política norte-americana que nos pudessem ser úteis. De se ressaltar que toda a crítica comunitarista que sucedeu Rawls demanda, em primeiro lugar, a compreensão da teoria desenvolvida por ele. E o primeiro contato com Uma teoria da justiça (1971) para o operador treinado no seio da tradição jurídica brasileira somente se configura uma experiência proveitosa acaso se tenha a exata noção de que os contornos da igualdade, da equidade, da justiça e do bom possuem matrizes completamente diversas nos dois sistemas.

Do artigo intitulado Qual o sentido de Rawls para nós? (Abreu, 2006) extraemse elementos que possibilitam uma melhor compreensão, de fato uma tradução, daquela noção de justiça como equidade (fairness) pensada por Rawls, adaptada à linguagem usual da tradição jurídica brasileira:

A ideia de justiça como equidade então poderia ser traduzida da seguinte maneira para um leitor brasileiro: é o procedimento que garante a possibilidade igual para todos de escolherem os princípios da justiça que melhor representem aquilo que é razoável para cada um, sem influências que possam, de alguma maneira, distorcer a igualdade fundamental entre todos; em outras palavras, a posição original e do véu da ignorância etc. são instrumentos que permitem, pelo menos no plano do pensamento, a emergência da igualdade substantiva dos cidadãos como parâmetro de construção do político. O ponto é que a estranheza que sentimos diante das ideias de Rawls é um dado que desvela aspectos importantes da nossa tradição. Acredito que a estranheza se baseie em duas diferenças importantes: o tipo de individualismo suposto na justiça como equidade e o fundamento das regras de cooperação social. (ABREU, 2006, ob. cit. p. 160).

Abreu (2006) entende a tradição do pensamento jurídico brasileiro como contida num sistema mais amplo de valores e ideias e, portanto, formada não apenas pelas elaborações conscientes da doutrina e da jurisprudência em face dos enunciados 
normativos das diversas regras jurídicas presentes no ordenamento positivo brasileiro, "mas principalmente pela relação disso com a prática social da atividade jurisdicional e as categorias culturais mais amplas que, muitas vezes, o campo do direito reelabora de uma maneira muito particular". Essa visão é bem relevante para as considerações que estamos a tecer.

Nesse prisma, o direito deve ser percebido como um produto da sociedade, apesar de sua relativa autonomia para com outras esferas da realidade social, em função da tradição de seus métodos próprios e de sua prática.

Em Rawls, a justiça, ou melhor, a noção do que seja uma sociedade justa passa pela vinculação da ideia em torno da posição original, para se alcançar o equilíbrio reflexivo a partir de um método de diálogo progressivo estabelecido por ele com o seu leitor, segundo o qual se presume consenso acerca de determinados valores presentes numa tradição política e jurídica - que são compartilhados entre autor e leitor - e materializados através de julgamentos intuitivos. ${ }^{15}$

Para Abreu (2006):

A leitura de Uma teoria da justiça pode ser percebida, então, como a proposta de um encontro hermenêutico, do leitor com o mundo do texto (Cf. Ricoeur, 1986), mundo construído de forma a trazer ao primeiro plano uma tradição de pensamento a partir dos juízos intuitivos do leitor. Dessa perspectiva, é possível propor que, em Rawls, a propriedade hermenêutica do encontro é ao mesmo tempo um instrumento metodológico e político: metodológico porque constrói o caminho que o texto nos propõe, e, nesse sentido, o critério autorreferenciado está presente na própria estrutura do texto; o encontro também é político, porque ele pretende uma modificação daquilo que, com muito cuidado, poderíamos chamar de "política íntima" - a ideia é que a maneira de ver o mundo do indivíduo tem consequências políticas e que, inversamente, certos tipos de mudanças políticas (do tipo que, por exemplo, Rawls propõe) exigem uma modificação na maneira como os indivíduos veem o mundo - ou pelo menos, como veremos adiante, veem a política. (ob. cit. p. 154).

O ponto central da tese de Rawls da obra em questão refere-se à proposição de critérios a partir dos quais seria possível discutir o justo. E esses critérios, ao fim e ao cabo, ainda que se pense nas instituições, decorrem das influências que os seres humanos exercem uns sobre os outros, seja no campo da moral ou no campo da ética. Notadamente, a posição social ocupada por cada indivíduo que se propõe a emitir juízos de justiça possui peso destacado nesse jogo e isso impacta diretamente a noção de igualdade em Rawls, uma vez que o ponto de partida (véu da ignorância) 
- condição para a eliminação das diferenças individuais naturais - é o próprio reconhecimento da desigualdade entre os sujeitos membros de uma dada sociedade. ${ }^{16}$

Aproximando a abordagem de Rawls relativamente aos conceitos de igualdade e em especial de justiça com equidade para o problema enfrentado pela Comunidade do Horto, a partir do mapeamento analítico dos diversos discursos políticos em torno da questão (traduzidos para o campo jurídico através das manifestações que encontramos no processo administrativo que temos como objeto de estudo), poderíamos, em tese, estar aptos a construir ou ao menos delinear uma conjectura que nos permitiria encontrar qual seria a decisão mais racional, ou seja, a mais justa depois de colocados todos os pratos à mesa.

Contudo, as lições de Rawls, aqui valiosas para a aproximação com a doutrina norte-americana, servem muito mais à filosofia do que à teoria política. Nossa intenção, como dito no início, é trilhar um caminho que se situe entre a norma jurídica e a realidade social. Não se trata, pois, de pressupormos uma sociedade idealmente justa. Trata-se de voltar os olhos à realidade.

A complexidade das relações entre os mais diversos atores envolvidos no processo administrativo que trata do Jardim Botânico do Rio de Janeiro permite uma abordagem voltada para a percepção, no campo da prática, de como o direito à moradia se situa diante do discurso do tombamento do Jardim, da preservação ambiental e da expansão da botânica, assim como em qual medida o poder público tem enfrentado esse sensível problema e definido a maneira de execução de suas políticas para o local. E as lições dos comunitaristas norte-americanos são essenciais para o exercício de analisar práticas institucionais.

O professor britânico radicado nos Estados Unidos Alasdair MacIntyre, talvez o maior nome da crítica comunitarista contemporânea, no clássico Depois da virtude (1981), ${ }^{17}$ ao contrário de representantes da filosofia analítica, que tradicionalmente buscam generalizar as concepções morais a partir de uma ideia fulcrada na racionalidade, apresenta uma descrição histórica em torno da ética, a fim de iluminar o problema moderno das "incomensuráveis" noções morais, dos vários discursos originados dessas noções e dos conflitos sociais a partir daí surgidos. Seu argumento é construído a partir das tradições humanas, inclusive das tradições valorativas ao longo dos séculos. Nessa linha, a comunidade seria moldada pela tradição das práticas $^{18}$ humanas e o indivíduo seria guiado por ela, até porque ele já nasce inserido em uma dada comunidade, ou seja, o indivíduo é a ela subserviente, e não o contrário.

Já para o individualismo liberal de Rawls, a comunidade é simplesmente um campo no qual cada indivíduo busca a própria concepção de boa vida, e as instituições políticas existem para proporcionar um nível de ordem tal que essa atividade autodeterminada se viabilize. Cooperação social, então, significa estabelecer regras comuns pelas quais vamos instituir nossas limitações, bem como nossa liberdade de perseguir os bens internamente desejados. Rawls sustenta que o governo e as leis são 
(ou devem ser) neutros entre conceitos rivais da boa vida para os homens, e, por conseguinte, embora caiba ao governo promover a obediência às leis, na visão liberal não é função legítima do governo inculcar nenhuma perspectiva moral nas pessoas. Na história da humanidade, essa não se mostra uma perspectiva verdadeira.

MacIntyre (1981), tomando como pressuposto a ocorrência de uma catástrofe que tenha colocado em verdadeira desordem a cognição humana em relação aos significados da moral, sustenta como hipótese que a linguagem da moralidade também se encontra nesse estado de grave desordem, em escala global. ${ }^{19}$ Para o autor, dispomos apenas de fragmentos de um esquema conceitual, ou seja, partes das quais faltam os contextos de onde derivam os seus significados: "temos, na verdade, simulacros da moralidade, continuamos a usar muitas das suas expressões principais. Mas perdemos - em grande parte, se não totalmente - nossa compreensão, tanto teórica quanto prática, da moralidade” (p. 15). De se destacar os dizeres abaixo:

O esquema do declínio moral que essas observações pressupõem seria, como afirmei anteriormente, um esquema que exigiu a discriminação de três estágios distintos; o primeiro, no qual a teoria e a prática normativas e, mais especialmente, morais, contêm genuínos padrões objetivos e impessoais que proporcionam justificativas racionais para as normas, atos e juízos particulares que são, por sua vez, suscetíveis de justificativa racional; um segundo estágio, no qual existem tentativas malsucedidas de garantira objetividade e impessoalidade dos juízos morais, mas durante o qual o projeto de proporcionar justificações racionais por meio de padrões, como também para os próprios padrões, se degrada continuamente; e um terceiro estágio, no qual as teorias do tipo emotivista conquistam ampla aceitação implícita devido a um reconhecimento geral implícito na prática, embora não na teoria explícita, de que não se pode garantir a objetividade e a impessoalidade. (ob. cit., p. 44-43)

Nesse compasso, assevera que a característica mais marcante da linguagem moral contemporânea é a sua utilização para expressar discordâncias e o atributo fundamental dos debates que reverberam essas discordâncias é o seu caráter interminável. Por evidente, o discurso dos tribunais, mesmo que sob o abrigo das tradições e métodos jurídicos, nas hipóteses em que lidam com multi-interesses albergados pela lei e pela plausibilidade moral de cada argumento adversário, também reflete essa característica.

Discorrendo sobre o assunto, MacIntyre (1981) aponta três razões para a eternização desses debates morais na sociedade: a incomensurabilidade conceitual dos argumentos (cada premissa lançada em cada discurso adversário emprega um conceito normativo ou avaliativo bem diferente uma das outras); o disfarce das argumentações que se materializam sob o manto de racionais impessoais (o elo 
especial entre o contexto da elocução e a força da justificativa, que sempre se mantém no caso de expressões de preferências ou desejos pessoais, se rompe no caso de elocuções morais ou valorativas); a diversidade de origens históricas das premissas, conceitualmente distintas e incomensuráveis, das argumentações adversárias que são expostas nos debates morais contemporâneos.

Diante dessa problemática e na tentativa de desemaranhar as afirmações diversas e adversárias historicamente presentes na teoria e na filosofia política, MacIntyre propõe uma abordagem diferente acerca da virtude:

O que (...) proporciona de maneira semelhante a fundamentação necessária para tornar inteligível o conceito de virtude? É na resposta a essa pergunta que se torna claro o caráter complexo, histórico e multifacetado do conceito central de virtude, e cada um desses estágios tem seu próprio contexto conceitual. O primeiro estágio requer uma explicação contextualizadora do que chamarei de prática, o segundo, uma explicação do que já caracterizei como ordem narrativa de uma vida humana singular, e o terceiro, uma explicação muito mais completa do que a que elaborei até agora do que constitui uma tradição moral. Cada estágio posterior pressupõe o anterior, mas não o contrário. Cada estágio anterior é modificado e reinterpretado à luz de cada estágio posterior, mas também oferece um constituinte essencial de cada estágio posterior. O progresso no desenvolvimento do conceito está intimamente ligado à história da tradição da qual forma o núcleo, embora não a recapitule de maneira direta. (ob. cit., p. 314-315).

Mais adiante, na mesma obra, complementa:

Que as virtudes precisem ser, inicialmente, definidas e explicadas com base na noção de prática, de forma nenhuma implica a aprovação de todas as práticas em todas as circunstâncias. Que as virtudes (...) sejam definidas, não nos termos de práticas boas e certas, mas de práticas, não implica que as práticas conforme realizadas em determinadas ocasiões e locais, não precisem de crítica moral. E não faltam recursos para tal crítica. Em primeiro lugar, não há incoerência em apelas aos requisitos de uma virtude para criticar uma prática. Pode-se definir inicialmente a justiça como uma disposição que, à sua maneira especial, é necessária para sustentar as práticas; disso não se segue que não se deva condenar as transgressões à justiça ao se buscar atender os requisitos de uma prática. (ob. cit., p. 336-337).

É preciso salientar que os comunitaristas rejeitam a ideia de que os valores que guiam a política podem ser justificados num sentido lógico, a partir de uma primeira 
premissa indubitável e, então, gerar padrões de ações na política que possam ser fundados em qualquer pensamento racional. Na esteira do pensamento comunitarista, as instituições políticas - que bem representam a consecução das práticas humanas geram expectativas da coletividade e, quando falham em sua missão, fomentam a descrença das pessoas. Esse argumento também está presente em Michael Walzer, em Spheres of Justice (1983).

Aliás, informado pelas ideias centrais de Walzer, o professor da Universidade da Califórnia, Goodwin Liu (2008) ${ }^{20}$, abordando o reconhecimento judicial de direitos sociais, argumenta que a legitimidade desse reconhecimento depende de modos de raciocínio socialmente situados que se sustentem não em princípios morais transcendentes de uma sociedade ideal, mas aos significados culturalmente e historicamente contingentes de determinados bens coletivos em nossa própria sociedade. Para Liu, a existência de um direito social depende, prima facie, de programa previsto em legislação, daí porque os tribunais judiciais, de maneira geral, deveriam se limitar a exercer um papel de aceleração ou de correção na implementação desses direitos.

Ademais, uma vez que as concepções morais compartilhadas pela sociedade são, em última análise, sujeitas à revisão democrática, ainda que bem lentamente, os tribunais não podem fixar indefinidamente os exatos contornos de um direito social. Dessa maneira, as manifestações institucionais acerca dos direitos sociais refletem mais o caráter contingente dos julgamentos sociais coletivos do que a lógica de uma teoria moral abrangente.

No exercício de politologia que ora pretendemos realizar, essas nuances restarão explicitadas na prática. Verá-se como, no caso concreto, sob a alcunha de racionais, os argumentos acabam se perdendo por não possuírem a mesma estrutura de premissas, por não considerarem fatores históricos e por refletirem uma cultura essencialmente emotivista para a apreciação de problemas sociais. É nessa linha de pensamento que se torna viável a análise de processo administrativo (nosso objeto de pesquisa), que reúne em seu bojo interesses tão complexos e diversos entre si.

\section{Contexto dos fatos: O CASO do Jardim BotÂnico do Rio de Janeiro}

No Brasil, na segunda metade dos anos 1980, mais de duas centenas de ações judiciais de reintegração de posse - que até hoje desafiam o Judiciário - foram propostas pelo poder público brasileiro, então representado pelo já extinto Instituto Brasileiro de Desenvolvimento Florestal (IBDF). Essas ações objetivaram a retomada de áreas onde se situam atualmente 621 habitações - a Comunidade do Horto, que se localiza dentro dos limites de propriedade da União Federal onde também fica o Jardim Botânico do Rio de Janeiro. Deve-se contextualizar que, no mesmo ambiente, encontra-se ainda uma das sedes do Sepro, que conta com aproximadamente 2 mil funcionários trabalhando no local. 
O pólo ativo dessas ações judiciais, tendo em vista as profundas alterações orgânicas por que passou a Administração Pública no período - com a promulgação da Constituição da República e a introdução de diversas novas leis estruturantes - foi sucedido pelo Ibama, depois Ministério Público Federal e, finalmente, pela Advocacia-Geral da União.

Em regra, os espaços territoriais utilizados não se confundem, não se descartando, contudo, esse tipo de ocorrência. Certo é que a proximidade e os tênues limites sempre permitiram uma comunicação e uma interação contínua entre os múltiplos interesses latentes sobre a questão.

Deve-se repisar que toda a área (parque e comunidade) pertence à União e é, em tese, gerida pelo Instituto de Pesquisas Jardim Botânico do Rio de Janeiro (IPJBRJ), autarquia federal vinculada ao Ministério do Meio Ambiente. Assim, todas as implicações resultantes desse regime, especialmente relativos à personalidade jurídica própria (com natureza de direito público), autonomia administrativa, financeira e para ajuizar ações são inerentes à instituição. ${ }^{21}$

A origem do problema é antiga e retroage especialmente ao início do século 19 , a partir da desapropriação da fazenda de engenho anteriormente pertencente a Rodrigo de Freitas Mello e Castro (que dá nome à famosa lagoa situada na zona sul da cidade do Rio de Janeiro), ${ }^{22}$ promovida, à época, por Dom João VI. Com a vinda da família real para o Brasil em 1808, o governante desejava implementar no local como de fato o fez - uma fábrica de pólvora e uma fundição de artilharia visando à proteção da Corte Portuguesa (havia temores inerentes às invasões napoleônicas na Europa). Tais instalações bélicas ali permaneceram até o ano de $1826{ }^{23}$ Também visava o governante à preservação e expansão da botânica, com o resguardo das espécies nativas europeias e sua adaptação ao Brasil, além do fomento ao cultivo de especiarias na Colônia, o que ensejou, ainda no ano de 1808, a instalação de um jardim de aclimação, logo depois denominado "Real Horto".

Levando-se em consideração que se tratava de local ermo, situado na zona rural distante do centro urbano onde se concentrava boa parte da população carioca, permitiu-se, nos anos seguintes, a progressiva instalação de residências para moradia dos trabalhadores da fábrica de pólvora, mas não só: nas décadas seguintes também foram ali se instalando, sem oposição por parte do poder público - gestor do espaço - funcionários, colaboradores, pesquisadores, enfim, estruturas e prestadores de serviços necessários ao bom funcionamento do próprio Jardim Botânico, além de ocupações de naturezas diversas que acabaram se desenvolvendo tolerada e naturalmente. ${ }^{24}$

A instalação de moradias no local, portanto, refletia mera conveniência à proximidade da força de trabalho então demandada na região. Foram, assim, ao longo da história, permitidas e, em dados momentos, até mesmo incentivadas pelo poder público. Havia total interação das pessoas com o meio ambiente, restando ausente qualquer preocupação para com questões relativas à eventual degradação ambiental. 
Em 1819, os portões do Jardim foram abertos à visitação restrita e, já em 1822, houve a abertura para o público geral com visitas monitoradas, o que contribuiu para que o parque, na década de 1870, se consolidasse como importante referência de convivência e turismo da cidade do Rio de Janeiro - faceta que permanece até os dias atuais -, propiciando que o espaço adquirisse suma importância na formação das características socioculturais da cidade. Em 1890, a visitação ao Jardim foi franqueada ao público geral, diariamente, e sem a necessidade de acompanhamento, medida que proporcionou a visita de cerca de $180 \mathrm{mil}$ pessoas entre abril de 1890 e julho de $1894 .^{25}$

Pari passu, no final do século 19, o parque começou a deixar para trás seu caráter eminentemente agronômico e foi ganhando uma dimensão mais acadêmico-científica, voltada às pesquisas botânicas, ensino e conservação da flora. Assim, a partir de 1890 foram criados o Herbário, o Museu e Biblioteca, tendo sido a coleção ampliada para incluir como objeto as espécies nativas brasileiras. No ano de 1910, a estrutura administrativa do Jardim Botânico do Rio de Janeiro era então responsável pelas pesquisas botânicas, culturas de plantas úteis, bem como pelo arboreto, o que já contemplava a moldura das atividades e objetivos do parque para o século $20 .{ }^{26}$

Em 1916, por meio da publicação do Decreto n. 11.904, de 19 de janeiro, o então Presidente da República Wenceslau Braz promoveu a anexação jurídico-formal do Horto Florestal ao Jardim Botânico do Rio de Janeiro, de modo que aquele se tornou uma seção deste. Até meados do século 20, o funcionamento e os objetivos do parque conviveram harmonicamente com as moradias que foram se instalando nos arredores da área de visitação. Importa salientar que, a partir de 1942, o Jardim Botânico teve sua administração vinculada ao Serviço Florestal, integrante da estrutura do Ministério da Agricultura, por meio da edição do Decreto presidencial n. 9.015, de 16 de março, o que não alterou o viés básico de suas atividades.

Na década de 1960, houve certa pressão de mercado para que grande parte da área do Horto Florestal fosse destinada a empreendimento imobiliário ligado ao Banco Nacional de Habitação (BNH), em consonância com a política habitacional nacional desenvolvida pelo regime militar. ${ }^{27}$ Essa pressão foi veementemente rechaçada por importantes expoentes da sociedade e cultura carioca e brasileira, como Pedro Calmon, Carlos Drummond de Andrade e Roberto Burle-Marx, que era, à época, conselheiro do Instituto do Patrimônio Histórico e Artístico Nacional (Iphan). ${ }^{28}$

Desse modo, em virtude das atividades desenvolvidas em seu território relativas à preservação ambiental, à pesquisa científica, aos equipamentos públicos de lazer e cultura, bem como em razão presença de edificações e monumentos de valor histórico, cultural, paisagístico, houve o tombamento de todo o conjunto paisagístico do Jardim Botânico e Horto Florestal, consubstanciado pela instrução de três atos administrativos, o primeiro já a partir do fim da década de 1930 e o último finalizado em 
1973. ${ }^{29}$ Até os dias atuais, no entanto, os órgãos públicos não possuem um consenso exato sobre o quê efetivamente foi objeto do tombamento.

Dentre os bens que compreendem parte relevante do patrimônio imaterial do Jardim Botânico, destacam-se o arboreto, onde são encontrados, além das coleções vivas, estufas francesas do final do século 19 e monumentos históricos, chafarizes e obras de arte de diversas origens e autores. Do patrimônio arquitetônico, não se pode deixar de mencionar a edificação que um dia foi sede do Engenho Nossa Senhora da Conceição da Lagoa, a Casa dos Pilões, o Portão da Academia de Belas Artes e a Casa dos Cedros, todas datadas entre os séculos 16 e 19.

Tem-se que, até então, naquele contexto, a existência de moradias e de outras estruturas edificadas, estranhas ao objeto do Jardim, pareciam não incomodar o poder público ou interferir no bom funcionamento dos espaços de pesquisa e visitação.

Esse comportamento perdurou até a década de 1980, quando a presença dos moradores e de suas habitações começou a sofrer fortes impugnações, especialmente na esfera judiciária. Percebeu-se, no mesmo período, um crescimento exponencial do número de habitações erguidas na área e constatou-se que boa parte dos moradores já não mais tinha quaisquer vínculos com a Administração Pública aptos a justificar a permanência no local. Desse modo, foram propostas as centenas de ações judiciais de reintegração de posse.

Muitas dessas ações judiciais começaram a apresentar resultados apenas no início do século 21, tendo a Justiça Federal no Estado do Rio de Janeiro sentenciado a procedência dos pedidos e o direito de a União ser reintegrada na posse dos imóveis localizados dentro da área do parque a ela pertencente.

O cumprimento e execução dessas determinações frequentemente encontram variáveis decorrentes da realidade social inerente à Comunidade do Horto, da compreensão acerca do novo paradigma conferido nos últimos anos à gestão do patrimônio da União à luz do direito à moradia, especialmente pelo Poder Executivo (autor dos pedidos de reintegração), e do regime jurídico especial de preservação e conservação a que está submetida a área do Jardim Botânico.

Deve-se salientar que a maior parte das ações judiciais encontra-se com seu curso suspenso desde 2010, quando a Advocacia-Geral da União formulou requerimentos nesse sentido, fundada na perspectiva de resolução administrativa interna do problema, mediante instauração de Câmara de Conciliação para tal fim. Nesse ponto, a maioria dos juízes mostrou-se sensível, confiando na capacidade de a Administração entabular política coordenada de gestão daquela área pública ocupada por apenas 621 moradias e outras edificações estranhas aos fins institucionais do Jardim.

Há de se ponderar, contudo, que a CCAF não constitui a primeira tentativa de resolução administrativa do caso. Os Ministérios do Planejamento, Orçamento e Gestão e do Meio Ambiente, ainda no ano de 2004, através de portaria interministerial, 
constituíram comissão conjunta que tinha por finalidade promover estudos técnicos e propor soluções para o problema. ${ }^{30}$

A referida comissão, que contou com a participação de representantes da SPU e do IJBRJ, mesmo tendo apontado que a resolução do problema passa por uma ação de governo mais ampla que extrapolaria os limites do grupo, chegou a apresentar um relatório no início de 2007, com diversas hipóteses para a resolução da questão, propondo medidas que iam desde a retirada integral das ocupações, com realocação dos moradores em outra área destinada pelo poder público, passando por soluções intermediárias, até a manutenção integral das famílias, com possíveis remanejamentos internos dentro da própria Comunidade do Horto, em virtude de moradias localizadas em áreas consideradas de risco. ${ }^{31}$

Pois bem. Cabe-nos a esta altura expor os dados relativos à Comunidade do Horto.

Observe-se que por conveniência da nomenclatura, temos neste texto denominado de Comunidade do Horto o conjunto de aglomerados residenciais compreendido pelas moradias instaladas dentro dos limites de terreno da União onde também funcionam áreas, edificações, e equipamentos afetos ou não ao Instituto de Pesquisas Jardim Botânico do Rio de Janeiro.

Para melhor compreensão dos complexos fatores que influenciam na elaboração e execução de políticas que visam à resolução do problema existente no local, é preciso trazer à baila algumas informações que refletem o perfil da comunidade que ali se instalou ao longo do tempo.

Dados do registro cadastral do Instituto de Terras do Estado do Rio de Janeiro (ITERJ), colhidos a partir da década de 1970, indicam um aumento sensível do número de habitações na localidade. Segundo levantamentos feitos pelo Instituto nos anos de 1975 e 1985, em dez anos, a quantidade de casas subiu de 377 para 408, o que representa um crescimento de 7,6\%. Já em 2007, de acordo com números de relatório elaborado pela já mencionada comissão interministerial, a quantidade de casas constatadas era de 589, um crescimento aproximado de 44\% em 22 anos. ${ }^{32}$

No ano de 2010, com vistas a subsidiar a atuação do poder público, especialmente da Secretaria do Patrimônio da União, um novo estudo foi elaborado pela UFRJ com vistas a fornecer dados sobre a extensão das áreas ocupadas, bem como quanto ao perfil socioeconômico da comunidade. O referido levantamento fornece e possibilita uma visão de conjunto quanto a aspectos particularmente relevantes do quadro sócio-territorial relativo ao conflito existente, constituindo o elemento disponível mais sólido para que seja traçado o perfil da comunidade.

Os extratos do mencionado estudo, publicados pelo jornal $O$ Globo em sua edição de 14 de outubro de 2010, apontam a existência de 621 casas identificadas (o que representa um crescimento de 5,15\% em relação aos dados de 2005), distribuídas em 11 setores espalhados por toda a extensão da área pertencente à União desta forma: Dona Castorina (101 habitações); Pacheco Leão I (76 habitações); Solar da Imperatriz 
(62 habitações); Pacheco Leão II, III, IV (28 habitações); Pacheco Leão V (68 habitações); Grotão I (26 habitações); Morro das Margaridas (40 habitações); Caxinguelê (61 habitações); Grotão II (95 habitações); Vila na Major Rubens Vaz, n. 64 (40 habitações); e Vila na Major Rubens Vaz, n. 122 (24 habitações).

O relatório da UFRJ contabilizou 1.890 moradores em 573 residências. Em relação à renda familiar declarada, 441 famílias (71,7\% do total) possuem renda de zero a cinco salários mínimos, sendo que 277 têm renda de até três e o restante (134) superior a três e inferior a cinco salários mínimos. Do universo cadastrado pela UFRJ, em 121 unidades habitacionais (21,1\% do total), as famílias possuem renda de mais de cinco e até dez salários mínimos, sendo que 5,6\% (32 famílias) possuem renda superior a dez salários mínimos. Apenas nove famílias (1,6\% do total) não informaram a sua faixa de renda.

Outro indicador relevante diz respeito ao tempo de moradia das famílias entrevistadas e cadastradas pelo estudo da UFRJ. Dos dados apresentados, verifica-se que 316 famílias residem no local há mais de quarenta anos, o que corresponde a 55,2\% do total, e apenas 2,3\%, ou seja, 13 famílias, habitam a localidade há menos de cinco anos.

Segundo o estudo da UFRJ, o setor que teve maior expansão no número de casas cadastradas foi a "Estrada Dona Castorina”, que saltou de 40 famílias em 2007 para 95 em 2010, um aumento de 138\% em três anos. É relevante mencionar que, entre os imóveis cadastrados, o estudo da UFRJ confirmou que treze casas foram negociadas (vendidas ou alugadas) nos cinco anos anteriores à sua elaboração.

\section{As POlíticas de GESTÃo doS IMÓVEIS DA UNIÃO:}

\section{a Secretaria do Patrimônio da União}

Como o Jardim e a Comunidade do Horto situam-se em área pública federal, interessante neste momento de nossa jornada é a exposição de um quadro de ações capitaneadas pelo órgão do governo brasileiro responsável pela elaboração e execução de políticas voltadas para a administração e a gestão dos bens imóveis da União.

Que se deixe assentado que nas hipóteses de utilização de imóvel da União por órgão ou entidade da administração pública federal para o desenvolvimento de atividades finalísticas, ato este efetivado normalmente por meio da lavratura de termo de entrega, restringe a utilização do imóvel para aqueles fins determinados no instrumento de utilização.

No caso do Jardim, até setembro de 2012 não havia qualquer instrumento de destinação formalizado pela SPU ao IJBRJ e nem notícia do registro imobiliário da área, em que pese ter sido autorizado pela Ministra do Planejamento desde setembro de 2011.33 Os órgãos e entidades públicas envolvidos no problema não possuem um consenso quanto aos exatos limites territoriais do imóvel e quais seriam os espaços necessários ao 
funcionamento e expansão do Jardim. Outrossim, o TCU afirma em recente relatório técnico que dez dos onze setores encontram-se inseridos em áreas tombadas pelo Iphan. Também não há consenso sobre esse ponto, como adiante delinearemos.

Consideradas essas informações específicas do nosso objeto de estudo, passemos a tratar das políticas abrangentes de gestão do patrimônio imobiliário da União. De forma geral, essa atribuição decorre de competência conferida por lei à Secretaria de Patrimônio da União (SPU), ${ }^{34}$ órgão do Ministério do Planejamento, Orçamento e Gestão.

Deve-se salientar que as diretrizes dessa gestão têm passado por um processo político contínuo e gradativo de mudança na visão, especialmente nos últimos dez anos. Contribui e influi substancialmente no desenrolar deste processo a previsão, na Constituição Federal de 1988, de dispositivo inserto no título dos direitos e garantias fundamentais com o comando a propriedade atenderá a sua função social, ${ }^{35}$ que repercutiu na formulação de políticas públicas voltadas para o atendimento desse dispositivo nos últimos anos.

A partir da elaboração da Política Nacional de Gestão do Patrimônio da União (PNGPU) no ano de 2003, ${ }^{36}$ a busca pela materialização da função social dos bens imóveis da União refletiu a missão institucional definida em Planejamento Estratégico da própria SPU, qual seja: "conhecer, zelar e garantir que cada imóvel da União cumpra sua função socioambiental, em harmonia com a função arrecadadora, em apoio aos programas estratégicos para a Nação”.

Deve-se frisar que até o fim do século 20, a principal característica da gestão era privilegiar o uso dos bens com vistas a gerar receitas e reduzir custos operacionais para o governo federal. De modo geral, a terra e o direito à propriedade eram tratados sob a ótica da acumulação de riquezas, tendo como consequência a exploração da propriedade em benefício - especialmente econômico - de seu proprietário. Tal lógica estendia-se também à propriedade imobiliária da União, pelo menos até o início deste século, quando ela passou a ser explicitamente revista. ${ }^{37}$

A inclusão do atendimento da função social como orientação da utilização e destinação dos imóveis públicos federais rompeu com o paradigma até então conferido à função de arrecadação e, ao mesmo tempo, com a lógica de alienação de imóveis não utilizados no serviço público como forma de redução de custos operacionais e ampliação de receitas.

Evidentemente, a expressão função socioambiental talhada na missão institucional do órgão traz um amplo leque possível de significados, de modo que a política adotada para a resolução de conflitos fundiários pode ser amoldada de acordo com as realidades encontradas em cada caso particular.

Nessa esteira, o patrimônio imobiliário passou a ser visto como recurso estratégico a ser aplicado no apoio às políticas públicas voltadas para a inclusão social. Essencialmente, portanto, essa nova visão de gestão reflete uma convergência para com 
os programas públicos que visam à promoção do desenvolvimento sustentável e do crescimento econômico, com redução de desigualdades por meio da inclusão social.

A SPU tem entendido que o alinhamento de suas ações para fins de materialização dessa função social insculpida em sua missão institucional passa pela primazia da regularização fundiária de interesse social de imóveis já ocupados por famílias de baixa renda, bem como apoio a programas de provisão habitacional aos imóveis que se encontrem vazios ou subutilizados. ${ }^{38}$ Para tanto, o órgão tem se valido de parcerias com outros entes da federação, especialmente municípios.

Ademais, o orçamento global da SPU experimentou um substancial aumento desde 2003, passando de $\mathrm{R} \$ 18,26$ milhões previstos na lei orçamentária daquele ano para R \$ 56 milhões constantes da lei orçamentária de 2010. ${ }^{39}$

Mesmo com a mudança da linha de atuação, a arrecadação no período também subiu exponencialmente, de R \$ 195,7 milhões em 2003 para R \$ 626,5 milhões em $2010,{ }^{40}$ resultado do aparelhamento do órgão e do aumento do número de imóveis identificados e cadastrados.

Nesse novo modelo de gestão, entre 2003 e 2010, 157.754 famílias foram beneficiadas em todo o país por atos administrativos de regularização fundiária efetivados pela SPU, totalizando áreas com extensão global de $101.531 .008,41 \mathrm{~m}^{2}$, ao passo que 14.154 famílias foram contempladas com áreas da União destinadas a programas de provisão habitacional, totalizando 3.034.468,46 $\mathrm{m}^{2}$ de terreno. ${ }^{41}$

Contribui sobremaneira para esse modelo de atuação da SPU o respaldo jurídico-normativo conferido por legislações aprovadas desde a edição da Constituição, que se voltaram para o reconhecimento formal de ocupações de baixa renda, especialmente nos espaços urbanos, acreditando-se que a regularização jurídica dessas posses em áreas públicas significa promoção de inclusão social e cidadania.

No arcabouço normativo que rege a matéria, destaca-se inicialmente a Lei n. 9.636, editada em maio de 1998, que, em sua redação original, já autorizava logo no art. $1^{\circ}$ o Poder Executivo, por intermédio da SPU, a "regularizar as ocupações e promover a utilização ordenada dos bens imóveis de domínio da União”. A edição da referida lei representa a superação jurídico-formal do paradigma da gestão patrimonialista dos imóveis da União, anteriormente regulado basicamente pelo Decreto-Lei n. 9.760, de 1946 (que ainda mantém alguns dispositivos em vigor, por não haver incompatibilidade material com regras atuais).

A Lei n. 9.636/98, posteriormente, sofreu importante reforma proveniente da Medida Provisória n. 335, de 23 de dezembro de 2006, cuja vigência foi prorrogada pela Presidência da República até a sua aprovação pelo Congresso Nacional, o que resultou na edição da Lei n. 11.481, de 31 de maio de 2007.

O supramencionado artigo $1^{\circ}$ teve a sua redação alterada para deixar claro que a gestão dos imóveis da União deve privilegiar o reconhecimento estatal das ocupações até então consideradas informais, de modo que o poder executivo federal está, a partir 
de então, legalmente autorizado a promover a "regularização das ocupações nesses imóveis, inclusive de assentamentos informais de baixa renda”.

Por outro lado e no mesmo sentido, editou-se a Medida Provisória n. 2.220, de 4 de setembro de 2001, que se propôs a regulamentar o art. 183 da Constituição Federal, ${ }^{42}$ tendo pioneiramente introduzido no ordenamento o instituto da concessão de uso especial para fins de moradia, com vistas a regularizar moradias em áreas públicas urbanas, a partir do reconhecimento dos ditos direitos subjetivos, uma vez que sua outorga é deferida àqueles que atendem aos requisitos objetivos nela delineados, ${ }^{43}$ independentemente da discricionariedade da Administração. ${ }^{44}$

Não bastasse, importante componente no plano operacional das políticas públicas de gestão das ocupações em áreas públicas voltadas para o reconhecimento formal foi a criação, em 2003, do Ministério das Cidades e da Secretaria Nacional de Programas Urbanos. A partir de ações concatenadas desse órgão, pela primeira vez foi entabulada uma política nacional para a regularização fundiária sustentável de áreas urbanas, que se concretizou no Programa Papel Passado, cujo objetivo fundamental funda-se no estímulo aos processos de regularização fundiária em áreas urbanas, especialmente quando pertencentes à União, Distrito Federal, Estados e Municípios, por meio de descentralização da execução, fomento ao acesso a recursos e desburocratização de procedimentos. ${ }^{45}$

Nesse prisma, foi também editada a Lei n. 11.977, de 7 de julho de 2009, importante marco legal que, além de superar entraves constantes de legislações anteriores, trouxe o regramento formal para a operacionalização da regularização fundiária planejada pelo governo federal. Curioso é que a própria lei, num esforço retórico, conceitua, em seu artigo 46, a regularização fundiária como o

conjunto de medidas jurídicas, urbanísticas, ambientais e sociais que visam à regularização de assentamentos irregulares e à titulação de seus ocupantes, de modo a garantir o direito social à moradia, o pleno desenvolvimento das funções sociais da propriedade urbana e o direito ao meio ambiente ecologicamente equilibrado.

A lei traçou ainda os princípios fundamentais da regularização fundiária (vide art. 48). ${ }^{46}$ Importa ressaltar, por oportuno, que mais recentemente foram promovidas algumas transformações na redação original da Lei n. 11.977, por meio da edição da Lei n. 12.424, de 16 de junho de 2011, visando adequar os ditames da legislação às demandas encontradas durante a implementação e execução do Programa Minha Casa Minha Vida.

Por derradeiro nesta seção, deve-se observar que a preocupação com a questão ambiental deve estar presente no desenho legal das políticas públicas de gestão de imóveis da União e de regularização fundiária, o que se verifica a partir de todas as normas jurídicas apontadas, refletindo a noção relativa à necessidade do uso sustentável dos solos urbanos, em harmonia e integração com a natureza. 
Nesse diapasão, cabe citar o art. 54 da Lei 11.977/2009, que abre a possibilidade de regularização fundiária em áreas de preservação permanente - APP, conforme definidas no Código Florestal (arts. $3^{\circ}$, II, e $4^{\circ}$ ). Destaca-se que essa opção somente se admite nos casos em que ocorra simultaneamente: ocupação anterior a 31 de dezembro de 2007, assentamento inserido em área urbana consolidada, e o estudo técnico comprovar que a intervenção programada implicará melhoria das condições ambientais relativamente à situação de ocupação irregular anterior.

Por sinal, essa harmonização entre desenvolvimento e meio ambiente saudável é objeto da mais recente preocupação das Nações Unidas quanto ao futuro da humanidade, especialmente a partir das mudanças climáticas constatadas em escala global nos últimos anos em decorrência da forte urbanização e concentração das populações nas cidades. ${ }^{47}$

Tem-se, pois, no início do século 21, em consonância com o novo paradigma da gestão de imóveis da União norteada pela função social da propriedade pública e com a atuação prática dos órgãos governamentais envolvidos, numa linha que se pode dizer essencialmente comunitarista, o reconhecimento da legislação quanto às facetas inerentes às possibilidades postas à disposição de gestores de políticas públicas habitacionais para a concretização do direito de moradia de famílias de baixa renda, por intermédio da regularização de suas posses e ocupações, dentro de determinados critérios.

\section{Do Judiciário ao Tribunal de Contas da União}

A compreensão do fenômeno social inerente à ocupação dessas áreas e das políticas voltadas para o local, especialmente destinadas às famílias de baixa renda, passa pela investigação acerca da participação de cada ator envolvido no problema, seus discursos e argumentos desenvolvidos para sustentar uma ou outra posição quanto à permanência ou não dos moradores na região.

As ações de cada ator e a interação mútua de suas práticas constituem importantes variáveis para a avaliação das políticas formatadas para a comunidade local. Como dito alhures, a permanência das moradias na área em que se desenvolveu a Comunidade do Hor to começou a sofrer sensível resistência a partir da década de 1980. À luz do novo paradigma de gestão de imóveis pertencentes à União, nos últimos anos, diversamente, a SPU adotou postura administrativa tendente a promover o reconhecimento formal das ocupações existentes no local, propondo sistematicamente a regularização fundiária das moradias, posição que tem encontrado significativas resistências de atores que integram o complexo processo de relações sócio-institucionais e influem diretamente nas diretrizes e implementação de soluções pensadas para a região.

Deve-se destacar que até setembro de 2012 nenhuma ordem judicial de reintegração de posse formalmente deferida pelo Judiciário chegou a ser efetivamente 
cumprida. A maioria dos processos judiciais encontra-se com a suspensão de seu curso deferida ou com o andamento sobrestado, em virtude de pedidos aviados pela Advocacia-Geral da União informando da instauração de Câmara de Conciliação e Arbitragem que visa a tratar do problema internamente, priorizando o diálogo entre os envolvidos.

Prudente mencionar que no ano de 2005 tentou-se executar ordem judicial de reintegração de posse contra ocupação individual, o que ocasionou forte resistência coletiva dos moradores. Narra-se o acontecido a partir dos dizeres constantes de artigo do presidente do IJBRJ, publicado na imprensa: ${ }^{48}$

na ocasião, os moradores resistiram à ordem judicial. A polícia, convocada pela Justiça para assegurar a reintegração de posse, recuou após enfrentamento com os ocupantes (...). O incidente, em 7 de junho passado, contou com a intervenção de profissionais ligados à defesa dos direitos humanos. Ao fim do dia, o juiz da $17^{\mathrm{a}}$ Vara Federal revogou a ordem de reintegração, evitando um confronto de consequências imprevisíveis.

Outro caso extremo - que aqui denominamos de caso Gracinda - pode ser analisado a partir de uma ordem judicial emitida em ação de reintegração de posse no ano de 2009, que determinou a retirada de moradora idosa - com 96 anos de idade e de baixa renda - da residência em que vivia há mais de sete décadas com a sua família.

Intimada na condição de representante legal da União para promover execução dessa ordem judicial, a Secretária do Patrimônio da União no Estado do Rio de Janeiro, adotando postura independente e desvinculada do Judiciário, em razão do iminente risco de retirada da moradora do local e da possibilidade de repetição dos conflitos havidos em 2005, invocando o direito à moradia titularizado pela idosa expropriada, resolveu lavrar contrato administrativo de concessão de direito real de uso, apoiado nos artigos $7^{\circ}$, Decreto-Lei 271/1967, e 18, $\S 1^{\circ}$ e $6^{\circ}$, I, Lei 9.636/1998. Com esse contrato, a ordem judicial não foi cumprida e a idosa permanece até os dias atuais em sua residência, desta feita sob o manto do reconhecimento formal de sua ocupação.

Esse caso deu ensejo à instauração de procedimento de controle pelo Tribunal de Contas da União, para averiguação do comportamento dos administradores públicos no caso concreto. Seguindo a tradição de sua atuação, o TCU ampliou o objeto de sua investigação e passou a focar no exame de todo o problema da Comunidade do Horto, tendo recentemente proferido decisão sobre todo o caso, ${ }^{49}$ cujos votos mais adiante passaremos a analisar.

Antes, contudo, é necessário voltarmos os olhos ao processo judicial que trata do caso Gracinda. Ressalte-se que nossa análise não tem qualquer preocupação com a apresentação ordenada de acordo com a forma processual utilizada para carrear as argumentações (petição inicial, contestação, pareceres, sentença, recursos, acórdãos), 
já que os fundamentos delineados praticamente se repetem nas sucessivas manifestações de cada ator envolvido e a sua ordenação não traria quaisquer contribuições significativas ao método ora proposto.

\section{I O Caso Gracinda: a AÇÃo de Reintegração de Posse n. 00.0932754-1}

Nessa ação, sob o mesmo pálio argumentativo das ações possessórias então ajuizadas na década de 1980, a União obteve pronunciamento judicial favorável à reintegração de sua posse no imóvel situado à Rua Pacheco Leão 1.235, casa 124, ocupado pela Sra. Gracinda dos Santos da Silva e sua família. Por longos anos, e depois de percorridas diversas instâncias judiciais, apesar do reconhecimento formal por parte do Estado-Juiz em relação aos direitos da União operado com o trânsito em julgado da sentença, não houve o cumprimento e a execução da ordem judicial, tendo permanecido a ré com sua família na moradia, ocupação essa que remonta a um período superior a setenta anos.

Já no ano de 2010, ao apreciar pedido de suspensão do processo formalizado pela Advocacia-Geral da União sob a justificativa de que a questão se encontrava pendente de resolução administrativa no âmbito interno da Administração (por meio da CCAF), o Juízo, assumindo postura jurídico-formalista perante os complexos problemas e conflitos fundiários na área, desconsiderou o pedido de suspensão processual formulado pela autora da ação e exarou a seguinte ordem:

trata-se de decisão transitada em julgado, mantida pelo STJ, determinando a reintegração de posse de bem público, pelo que não cabe ao órgão administrativo dispor do direito concedido. Sendo assim, em cumprimento ao acórdão supracitado, expeça-se o competente mandado de reintegração de posse em favor da União Federal, do imóvel localizado à Rua Pacheco Leão (...) Estrada do Grotão (...) Jardim Botânico, Rio de Janeiro (...) devendo o Oficial de Justiça, em caso de resistência, certificar o ocorrido.

Deve-se salientar que o próprio IJBRJ manifestou-se formalmente no processo judicial, aduzindo o seu desinteresse no cumprimento da ordem judicial de reintegração, naquela dada ocasião. Em momento seguinte, diante de novo pedido apresentado pela União visando ao não cumprimento da ordem de reintegração emitida, o julgador de primeira instância tornou a se manifestar, renovando a necessidade de execução da decisão anteriormente exarada e determinando seu cumprimento, desta feita impondo a aplicação de multa pessoal diária de 2 mil reais ao chefe da Procuradoria-Regional da União da $2^{a}$ região e à Superintendente do Patrimônio da União no Estado do Rio de Janeiro, em caso de descumprimento do comando judicial.

Diante da nova ordem judicial proferida, a União, por sua Advocacia-Geral, apresentou recurso de agravo ao Tribunal Regional Federal da $2^{a}$ região, procurando 
principalmente desconstituir a multa pessoal aplicada aos seus agentes e levar ao Judiciário a nova percepção do órgão gestor do patrimônio em relação à promoção do direito à moradia. Saliente-se que o agravo interposto pela AGU, ainda pendente de julgamento, suspendeu a execução da reintegração de posse. Chama a atenção a linha desenvolvida pela AGU em sua peça recursal:

não cabe ao Poder Judiciário imiscuir-se no mérito das políticas públicas de regularização fundiária levadas a efeito por ato da Secretaria do Patrimônio da União. Esse órgão optou por não mais prosseguir com todas as ações de reintegração de posse dos imóveis situados no Jardim Botânico, com exceção daquelas nas quais se discute eventual indenização por benfeitorias. (...) O Ministério do Planejamento, Orçamento e Gestão enxerga na concessão de uso de imóveis federais um instrumento para erradicar a pobreza e a marginalização e reduzir as desigualdades sociais (...). Existe a possibilidade de ser outorgada à agravada Título de Concessão de Direito Real de Uso para fins de moradia, na forma como estabelecido nos arts. $7^{\circ}$ do Decreto-Lei $271 / 1967$ e $18, \S \S 1^{\circ}$ e $6^{\circ}$, I da Lei 9.636/1998 (...). Assim, decisão da SPU no sentido de deixar de dar cumprimento à sentença de reintegração de posse referente ao imóvel ocupado representa o legítimo exercício de uma competência constitucional, a qual não cabe ao Judiciário adentrar (...). A proposta de regularização fundiária levada a efeito através da SPU não caracteriza ato de disposição do patrimônio federal, na medida em que a agravante preserva consigo os poderes de gozar, dispor e reivindicar o bem, recebendo a agravada tão somente o Direito Real de Uso Resolúvel do Imóvel.

A União não obteve sucesso no pleito de suspensão da ordem judicial, visto que a liminar pedida no recurso por ela apresentada foi indeferia. Na instância seguinte, conseguiu apenas desconstituir a multa aplicada aos seus agentes públicos.

Em virtude dos sucessivos fracassos da União em demover o Judiciário de executar sua ordem, na iminência da execução do comando judicial de reintegração, a SPU no Rio de Janeiro resolveu lavrar contrato de concessão de direito real de uso em favor da ré, fundamentando a prática desse ato administrativo no art. 18, II e $\S 1^{\circ}$, da Lei 9.636/98 em cumulação com o art. $7^{\circ}$ do Decreto-Lei 271/67. Perante o TCU, sustentou a SPU que se tratou de um ato excepcional, que era a única alternativa possível, que foi efetivado ato administrativo legal que não caracteriza disposição do patrimônio público, mas tão somente transferência do direito real de uso resolúvel.

De posse desse instrumento jurídico-formal emitido pelo poder público, a ordem judicial de retirada não obteve a concretude desejada pelo Juízo prolator e a 
ré, de uma forma ou de outra, permanece em sua residência localizada em propriedade pública da União até os dias atuais.

Nesse processo, percebe-se não apenas uma compreensão inadequada sobre o novo paradigma conferido à gestão do patrimônio da União em relação ao trato de ocupações de moradias nessas áreas pertencentes ao ente federal, mas também um completo desprestígio às políticas públicas voltadas à consecução do direito à moradia, que em nenhum momento chegou a ser objeto de apreciação pelo Judiciário.

Nota-se que o magistrado, diferentemente do que ocorreu na maioria das ações judiciais que foram suspensas a pedido da União (autora nesses processos), ignorou as tratativas administrativas voltadas para a solução do problema e os próprios pedidos formulados nesse sentido. O Judiciário, neste caso específico, tentou levar às últimas consequências posição legalista e dogmática (que já se demonstrou insuficiente e inadequada para resolver os conflitos fundiários do Jardim Botânico), insistindo na reintegração de posse que já não era mais aspirada na modelagem dos pedidos aviados pela autora quando ingressou com a ação judicial.

Não foram aplicados pelo Judiciário os mecanismos jurídicos já existentes na legislação brasileira e apresentados neste texto, que privilegiam a concessão de titulação formal de utilização de imóvel da União à luz da percepção da função social da propriedade e, por tal razão, representam importantes ferramentas para se lidar com um novo cenário das relações sociais, especialmente no caso das ocupações da Comunidade do Horto.

Pode-se afirmar, portanto, que os argumentos das decisões judiciais nesse processo encontram-se defasados, calcados em argumentos de autoridade como a indisponibilidade do interesse público, saltando aos olhos o fato de não ter havido discussão minimamente aprofundada sobre direito à moradia, sobre os novos instrumentos de destinação e meios de utilização de imóveis da União e, principalmente, sobre a atuação judicial se imiscuir em ações da administração pública, contribuindo não para a solução, mas para o acirramento do problema.

\subsection{A Questão no TCU}

Como dito linhas acima, o caso Gracinda ensejou a instauração de procedimento no âmbito do Tribunal de Contas da União, que proferiu recentemente decisão sobre o caso (datada de setembro de 2012). É importante frisar que o problema já havia sido submetido, tempos atrás, ao crivo do TCU, em fevereiro de 2001, quando a sua $2^{\text {a }}$ Câmara determinou ao IJBRJ a adoção de medidas para a correção e a prevenção de novas invasões de imóveis nos limites do patrimônio da União pelo qual é responsável. Como se observa da contextualização dos fatos a que procedemos alhures, a decisão da Corte de Contas do início da década passada não surtiu os efeitos práticos esperados, uma vez que novas ocupações foram constatadas ao longo dos anos 2000. 
Pois bem. Na sua recente decisão, o TCU produziu extenso relatório de levantamento, com minuciosa descrição das circunstâncias que envolvem o caso do Jardim. Deve-se ter em mente que o papel do TCU, à luz do art. 71 da Constituição Federal, visa à fiscalização quanto à legalidade dos atos administrativos praticados pelos órgãos e entidades públicas envolvidas na questão, bem como eventual aplicação de sanção aos gestores públicos responsáveis.

Para os fins pretendidos neste artigo, os pontos principais abordados pelo TCU residem nas circunstâncias em torno da legalidade da CDRU lavrada em favor de Gracinda e dos aspectos inerentes à abrangência do tombamento do Jardim.

Logo no início do relatório, nota-se a premissa sobre a qual parte a linha argumentativa desenvolvida pelo TCU:

a necessária expansão do Arboreto do JBRJ é extremamente prejudicada por ocupações indevidas feitas por pessoas físicas e jurídicas naquele Jardim com relevante degradação ambiental, com descumprimento da legislação sobre tombamento, e é agravada por atuações aparentemente ilegais de alguns gestores tendentes à formalização de regularização fundiária de interesse social nesta área sem o devido amparo legal.

Os auditores opinam que a tentativa da SPU em promover regularização fundiária na área interna do Jardim Botânico não tem base legal. Segundo manifestação do tribunal, somente o setor Dona Castorina estaria localizado fora do polígono de tombamento do Jardim. Contudo, o próprio Jardim, na sua condição de autarquia, até o presente momento, não definiu nem apontou concretamente quais seriam as suas reais necessidades de expansão, ou seja, quais equipamentos pretende implementar no local.

No que concerne ao tombamento, curioso é que não há certeza da Administração Pública quanto aos seus exatos limites. Constatamos manifestações imprecisas e contraditórias no bojo da documentação acostada ao processo administrativo n. 00405.008207/2010-50 (que tramita na CCAF/AGU) e no próprio relatório de levantamento produzido pelo TCU. A SPU alega que o Iphan não qualificou a área do Jardim e adjacências como integralmente abrangida pelos tombamentos. OTCU admite que a alegação da SPU é verdadeira, mas a rechaça, sob o seguinte argumento:

A interpretação histórica dos processos correlatos desse Instituto deixa claro que os tombamentos do Jardim Botânico e do Horto Florestal objetivam proteger a integridade dos seus territórios contíguos, abrangendo sem sombra de dúvida todas as suas respectivas áreas que lhe pertencem historicamente (vide peça 23, doc 45.343.178-9, e peça 24, doc 45.343.183-3). O IPHAN reforçou este seu entendimento na ata de 
7/2/2011 da Câmara de conciliação e arbitragem da administração federal, trazida aos autos por cópia pela própria defendente: "O Superintendente Regional do IPHAN informou que, dentro da área administrada pelo Jardim Botânico, são tombados: a) o acervo científico e paisagístico (...); b) construções específicas; c) sítios arqueológicos”. No que diz respeito às ocupações existentes na área, o IPHAN opina que as áreas acima da margem esquerda do Rio dos Macacos estão incorporadas ao conjunto urbano externo aos limites do Jardim Botânico e a regularização dessas áreas não afetaria o conjunto paisagístico do parque. Entretanto, a área no entorno do Solar da Imperatriz, bem como os núcleos do Grotão, Caxinguelê e Margaridas que conectam o horto ao arboreto não deveriam ser regularizadas por serem áreas relacionadas às atividades essenciais do Jardim Botânico, impactando indevidamente na paisagem do conjunto. (peça 82, doc 46.364.845-0, p. 22).

Como se vê, a Corte de Contas utiliza-se de interpretação histórica para sustentar a abrangência integral do tombamento. Certo é que o procedimento para o tombamento, especialmente aquele tocado no final da década de 1960, visava a impedir que parte da área fosse destinada à construção de grande empreendimento imobiliário do então BNH; nada falava acerca das simples habitações que já existiam no local, autorizadas pela própria autarquia. Note-se que o próprio relatório de levantamento indica a inexatidão relativa à abrangência do tombamento:

Um dos indícios de necessidade de atuação do TCU está no parecer, aprovado pelo Conselho Consultivo do Iphan, da lavra do Diretor do Museu Nacional Luiz Emygdio de Mello Filho (Ofício 28, de 31/121971 vide peça 24, p. 16-20 e 35-47), que acolhe o seguinte entendimento do paisagista Roberto Burle-Marx escrito em 04/07/1969 para, baseado na avaliação de que "as próprias autoridades vêm desrespeitando a legislação", requerer o tombamento do Horto Florestal. (...)

Pode-se considerar que, pela expressão "Jardim Botânico”, a autoridade administrativa, pretendeu colocar, sob proteção, a totalidade da área que recebe esse nome e, não apenas parte desse imóvel, onde se desenvolvem as atividades de proteção à flora.

Para tanto, poderia arguir-se o fato de que, caso houvesse ocorrido a segunda hipótese, ela seria especificamente declarada (...), mas, preferindo, pelo contrário, a expressão genérica "Jardim Botânico", é de acreditar que o objeto de proteção não foram apenas os exemplares da flora ou a área em que se encontravam, mas o espaço total designado por aquela expressão, no falar comum da cidade. 
O mesmo não se pode dizer em relação ao Horto Florestal, já que seu ato de proteção (...) foi redigido de modo mais apropriado, pois utilizou a expressão “conjunto paisagístico da área”, a qual, evidentemente, contém a totalidade da área do imóvel ocupado pelo Horto Florestal.

Relativamente a esse imóvel, pois, a extensão do ato de tombamento está caracterizada de melhor forma, mas seria interessante, porém, que a extensão da área tombada fosse também identificada com exatidão. Tendo em vista a maneira como foi feito o tombamento do Jardim Botânico e do Horto Florestal, sem que a área de proteção haja sido devidamente delimitada, nem expressamente citados os demais elementos indispensáveis ao equilíbrio ecológico, é de todo interesse e importância que o Jardim Botânico solicite à Subsecretaria do Patrimônio Histórico e Artístico Nacional [SPHAN] a fixação, com maior precisão, da faixa tombada e de seus bens, de modo a evitar dúvidas e problemas futuros.

Nada obstante, a instituição do tombamento e a definição dos seus exatos limites constituem fatores fundamentais para nortear o desenho e a implementação das políticas públicas voltadas para a Comunidade do Horto diante da realidade vivida no século 21. Mas, para tanto, é preciso que outras questões sejam previamente resolvidas: a definição da área para expansão das atividades do Jardim, o registro imobiliário da área em nome da União, a formalização de entrega do terreno à autarquia. Somente assim o Iphan, órgão legalmente responsável pela definição dos limites do tombamento, terá condições de proceder à sua tarefa. Como se vê, a desarticulação dos diversos órgãos públicos, como apontamos no início deste artigo, contribui para a eternização do problema.

Com relação ao caso Gracinda, o relatório de levantamento elaborado pelo TCU apontou ilegalidade no contrato de CDRU lavrado pela SPU. Veja-se:

No caso concreto sob exame, não houve esse tratamento positivado, logo o administrador público não tem competência para agir dessa forma, portanto essa alegada excepcionalidade foi contrato administrativo ilegal e consequentemente nulo 'ex tunc' por falta de requisito essencial, conforme ordenado na Lei 9.784/1999, art. 53, parte inicial do caput (“A Administração deve anular seus próprios atos, quando eivados de vício de legalidade”), e na Lei 8.666/1993, art. 59, caput ("A declaração de nulidade do contrato administrativo opera retroativamente impedindo os efeitos jurídicos que ele, ordinariamente, deveria produzir, além de desconstituir os já produzidos"). Contudo, como a jurisprudência desta Corte é tranquila no sentido de que, previamente à determinação para a rescisão de contratos administrativos ou de outros negócios jurídicos, deve ser dada a 
oportunidade do exercício do contraditório para aqueles que possam ser juridicamente afetados (vide $\S 3^{\circ}$ do Voto ref. ao Acórdão 2245/2006 Plenário), a anulação desse contrato de CDRU deve ser precedida de oitiva da pessoa que for potencialmente prejudicada por essa invalidação. Ao contrário do alegado, essa excepcionalidade não era a única alternativa possível, pois ela depende de prévia base legal para ser concretizada. Até o presente momento nem o RL nem outro documento do TCU acusou ter havido disposição do patrimônio público, logo não socorre a defendente alegar ter feito tão somente transferência do direito real de uso resolúvel. Por fim, apenas afirmar que cumpriu princípios e leis não socorre responsável flagrado no descumprimento de uns, de outros ou de ambos.

E mais adiante o relatório assevera:

Não cabe ao TCU ação destoante do respeito à coisa julgada, ainda mais considerando-se que "O juiz não deve ser mais clemente do que a lei" ('Judex non debet lege esse clementior') e que "a lei é dura, mas é a lei” ( 'Dura lex sed lex'). Com efeito, Decisão Interlocutória do juízo da $27^{\mathrm{a}}$ Vara Federal do Rio de Janeiro denegara pedido de suspensão do feito e determinara a expedição de mandado de Reintegração de Posse para o imóvel ocupado pela Sra. Gracinda Santos da Silva. Referida decisão impugnada apoiou-se no fato de que a União Federal sagrou-se vitoriosa no julgamento de Ação de Reintegração de Posse para esse imóvel, sendo defeso à SPU deixar de imitir a União na posse do bem, tendo em vista a indisponibilidade do interesse público. Realmente, não há república efetiva sem a supremacia do interesse público, conforme ilustrado pela tela "Os lictores levam ao cônsul Brutus os corpos de seus filhos", obra indicativa de que, como o bem público se sobrepõe ao privado, deve-se sacrificar as vantagens e até os afetos pessoais ao bem comum.

Normalmente a solução de conflitos entre direitos, entre princípios, ou entre ambos, se resolve pela identificação e pela priorização do atendimento do interesse público mais importante que for identificado no caso concreto.

Para o TCU, a partir de sua concepção dos contornos de interesse público, assevera que a resolução da questão não passa pela soma dos interesses individuais de particulares desejosos de permanecer morando naquela área da zona sul carioca, que possui um dos metros quadrados mais caros do país, mas sim pela efetiva aplicação desse interesse público, que pressupõe uma tradicional técnica do direito denominada de "balanceamento de princípios", a partir da qual prevaleceria o comando constitucional de que todos têm direito ao meio ambiente ecologicamente equilibrado. 
Ou seja, define-se aquilo que seria mais caro à sociedade e aplica-se pela via da imposição da força estatal. Note-se que o fato de o local representar um dos metros quadrados mais caros do País, ainda que por vias transversas, constitui parte fundamental da argumentação do TCU. Por evidente, essa técnica de balanceamento não se coaduna para com as conformações de justiça que destacamos na segunda parte deste artigo.

Aliás, falando sobre justiça e relacionando-a com a possibilidade ou não de tratamento diferenciado (ou individualizado) do caso das moradias da Comunidade do Horto, o relatório do TCU realiza os seguintes apontamentos doutrinários: ${ }^{50}$

Em todo caso, qualquer previsão de exceção na lei há de atender aos requisitos de legitimidade reconhecidos pela doutrina:

Para que um discrímen legal seja convivente com a isonomia, consoante visto até agora, impede que concorram quatro elementos: a) que a desequiparação não atinja de modo atual e absoluto, um só indivíduo; b) que as situações ou pessoas desequiparadas pela regra de direito sejam efetivamente distintas entre si, vale dizer, possuam características, traços, nelas residentes, diferençados; c) que exista, em abstrato, uma correlação lógica entre os fatores diferenciais existentes e a distinção de regime jurídico em função deles, estabelecida pela norma jurídica; d) que, in concreto, o vínculo de correção suprarreferido seja pertinente em função dos interesses constitucionalmente protegidos, isto é, resulte em diferenciação de tratamento jurídico fundada em razão valiosa - ao lume do texto constitucional - para o bem público.

E mais:

Conforme apontado em parte pela Enciclopédia Jurídica Soibelman, a Justiça é ilustrada milenarmente como uma deusa grega com uma venda nos olhos, que representa imparcialidade para dar o direito sem olhar a quem, com uma balança em uma mão, que representa o sopesar técnico das razões apresentadas, e com uma espada na outra, que representa a imperatividade das suas decisões. Assim, faz parte da missão do julgador assegurar-se de que a sua imparcialidade não seja afetada, nem mesmo pela condição socioeconômica de quem será beneficiado ou prejudicado pelos efeitos das suas decisões. Este preceito ético está refletido em leis no Brasil e no mundo, dentre as quais pode ser citado, por exemplo, o seguinte trecho da antiga legislação mosaica: "Não sereis injustos em vossos juízos: não favorecerás o pobre nem terás complacência com o grande; mas segundo a justiça julgarás o teu próximo” (Levítico 19,15). 
Para o TCU, não cabe ao juiz fazer acepção de pessoas quando a lei a ser aplicada não prevê tratamento diferenciado conforme características individuais, pois isso feriria os direitos fundamentais da igualdade entre as pessoas e da igualdade perante a lei. Ora, a própria legislação brasileira traz diferenciações essenciais para o resguardo da igualdade em casos como o do Jardim, elegendo o tempo de ocupação e a faixa de renda - para mencionar os dois principais - como critérios capazes de equilibrar as relações. É preciso ressaltar que as históricas tentativas de resolver o problema do entorno do Jardim, que sempre se balizaram em uma homogeneização dos interesses da comunidade que ali habita, mostraram-se instrumentalmente insuficientes ao longo dos anos.

No mais, quanto aos aspectos concretos do caso Gracinda, a Corte de Contas chegou a considerar (relatar) as suas especificidades, no entanto, rechaçou tais peculiaridades com típicos argumentos de autoridade, senão vejamos:

A fortiori, este Tribunal, por meio da Decisão 41 / 2000 - Primeira Câmara, mesmo considerando o disposto no art. 230 da Constituição Federal, fez prevalecer o entendimento de que uma pessoa, mesmo idosa e com necessidade econômica, não pode receber benefícios ilegais do Poder Público, ainda que seja para a concretização de um ou mais dos seus direitos e garantias fundamentais declarados pela Constituição Federal. Entre as razões preponderantes naquela apreciação, vê-se que "Não se questiona, absolutamente, o fato de alguém ajudar uma outra pessoa necessitada. Porém, deve-se ajudar a outrem dentro de um princípio legal e moral. Não se pode fazê-lo à revelia da lei, da ordem jurídica em vigor (...)”.

Entretanto, o presente contrato de CDRU foi concretizado por meio das e com as irregularidades acima elencadas nos subitens do motivo de audiência sob análise. Como já visto, tais meios ilegítimos não são justificados pelos fins legítimos apresentados.

Enfim, dignidade da pessoa humana é fundamento da República, é princípio constitucional, e é direito fundamental, mas não pode ser obtida nem preservada com indignidades, ilegitimidades e ilegalidades tais como esbulho. Assim, quem faz esbulho, ainda que impróprio e involuntário, não age de modo digno e por isso não pode bem estar sobre o imóvel esbulhado, nem por decisão judicial, para que não fique caracterizado esbulho de juiz.

Como se vê, o TCU atesta a ocorrência de esbulho no caso concreto, lançando mão de brocardos jurídicos clássicos que protegem a posse ou que a proíbem a sua ocorrência em bens públicos. No entanto, levando-se em conta que se trata de moradia existente no local há mais de setenta anos, os aspectos objetivos concretos à 
época da invasão de Dona Gracinda ao local sequer foram levados em conta e nem foi realizado qualquer esforço do órgão nesse sentido, o que leva a crer que, neste caso, o julgamento acabou por presumir a má-fé da moradora. Corroborando a existência dessa presunção, observe-se o que, mais adiante, assevera o relatório técnico do TCU:

não corresponde à verdade a afirmação de que há “ocupação consolidada há décadas no entorno da área do Jardim Botânico”. Na verdade, essa ocupação há décadas despreza e invade o tombado Jardim Botânico, logo essa invasão não merece prosperar sobre esse tombamento.

Chama a atenção que as conclusões do relatório de levantamento foram tomadas mesmo sem a prévia definição quanto aos limites do tombamento e, outrossim, quanto às reais necessidades de expansão do Jardim para o desenvolvimento de suas atividades finalísticas.

No que respeita aos votos dos ministros sobre o caso, dada a complexidade dos fatos, definiram-se apenas prazos e diligências administrativas, no âmbito de competência de cada órgão e entidade federais envolvidos, como medidas preparatórias (ou condicionantes) da implementação de solução - que ainda não se encontra delineada. Para o caso Gracinda, mesmo com todos os apontamentos dando conta da ilegalidade da medida tomada pela SPU, não houve aplicação de pena ao gestor, tampouco a decretação formal da nulidade do contrato lavrado. Ao contrário, a argumentação delineada pelo órgão gestor do patrimônio, dando conta da excepcionalidade do caso, foi integralmente acatada. Note-se o que diz trecho do voto condutor, exarado pelo ministro relator:

No entanto, procurando dar efetividade às novas ações que visem ao cumprimento da legislação que rege a matéria tratada nos autos, deve o Tribunal, com fulcro no art. 70, caput, e 71, inciso IX, da Constituição Federal, e na Lei Orgânica/TCU, fixar prazo certo para que os órgãos competentes executem as medidas necessárias. Para isso, o MPOG, a SPU, a SPU/RJ, o JBRJ e o Iphan deverão enviar ao TCU relatórios trimestrais sobre as medidas adotadas para: 1) cessão ao JBRJ, em regime de concessão de direito real de uso resolúvel, nos termos do art. 18 da Lei 9.636/98 c/c art. $1^{\circ}$, inciso I, do Decreto 3.125/99, do terreno historicamente pertencente ao Jardim Botânico, inclusive o Horto Florestal; e 2) que findem a delimitação da área essencial às atividades da autarquia e a conclusão da revisão dos tombamentos do JBRJ.

No tocante à emissão de CDRU em favor da Sra. Gracinda Santos da Silva, ressalto que o agravo interposto pela AGU suspendeu a execução da 
reintegração de posse, o que por si só, faria perder o sentido da concessão de uso. Apesar disso, as justificativas apresentadas pela superintendente da SPU/RJ podem ser acatadas, haja vista a individualidade do caso (senhora muita idosa com 94 anos, viúva e com filho deficiente, imóvel situado fora de interesse imediato do JBRJ e outros 48 imóveis da mesma localidade estarem em situação jurídica idêntica).

Por derradeiro, para esta seção de nosso artigo, trazemos à lume trechos do voto complementar exarado por ministro do TCU:

Todas essas áreas, com decisões favoráveis do Judiciário, devem ser imediatamente reintegradas ao Jardim Botânico. Já as áreas eventualmente objeto de decisão transitada em julgado, favorável aos invasores, devem ser desapropriadas pelo Poder Público, com o adequado pagamento de indenização aos ocupantes, para recomposição do parque e preservação do interesse público, em benefício de toda a população carioca. Todas as outras áreas devem ser imediatamente recuperadas para integral utilização pelo Jardim Botânico.

O pensamento constante do trecho supracolacionado, na linha da homogeneização dos interesses e da generalização do problema - que é multifacetado e complexo, por ser drástico, torna-se perigoso. Primeiro porque estabelece como critério a existência ou não de provimento judicial sobre cada caso. Ou seja, ao ocupante está lançada a álea da Justiça: as condições da habitação, do seu tempo, da faixa de renda e de alguma autorização que o poder público tenha porventura emitido no passado para que se habitasse o local, nada disso importa; relevante é a decisão judicial em cada dado processo, desconsiderando-se os entendimentos díspares de um juiz para o outro, a insensibilidade de umas e o excesso de sensibilidade de outras decisões. Segundo porque menciona a recuperação das áreas invadidas para fins de utilização pelo Jardim sem que a autarquia responsável tenha sequer definido as suas reais necessidades de expansão, os equipamentos que porventura pretende instalar e os locais que seriam utilizados.

Como temos demonstrado ao longo deste artigo, as questões que permeiam o caso do Jardim Botânico são altamente complexas. O TCU reafirmou decisões anteriores e fixou prazos para a execução de tarefas pelos órgãos envolvidos (o que já havia feito em oportunidades anteriores). Não se definiu, no entanto, questões preliminares que são básicas à formação de eventual solução. A Corte de Contas, ao contrário de constituir elemento catalisador de políticas públicas voltadas para o local, torna-se mais um ator do caso, o que enseja o acirramento dos discursos sobre o tema. 
Se a construção da argumentação delineada pela decisão do TCU traz contradições internas entre as suas considerações e os seus comandos, assim como acontece nas decisões judiciais quando demonstram seus argumentos de autoridade - como a indisponibilidade do interesse público ou quando desconsideram aspectos relevantes dos fatos e da própria legislação, se isso é problemático para as práticas institucionais, não é o mais grave. Em se tratando das virtudes nas práticas como pensada em MacIntyre, o pior dos problemas é o da incoerência da argumentação das instituições que operam o Direito e de como esses argumentos se materializam para a sociedade.

\section{CONCLUSÃo}

Numa sociedade real, os argumentos dos indivíduos sobre o que seria justo estão efetivamente influenciados pelas suas respectivas posições sociais, riqueza, valores religiosos, crenças pessoais, as escolhas éticas, a história pessoal, etc. Mais ainda, esses condicionantes representam posições sociais assimétricas, quer dizer, elas incorporam não apenas diferenças individuais, mas, sobretudo, desigualdades. Essas desigualdades, por sua vez, não são apenas o resultado do esforço pessoal numa situação de igualdade de oportunidades, mas são construídas e perpetuadas socialmente. Em outras palavras, os argumentos sobre o que seria justo numa sociedade real potencialmente - e na nossa opinião de fato - refletem, nalguma medida, as injustiças da própria sociedade.

No curso das últimas três décadas, o Judiciário mostrou-se uma arena inadequada para a resolução do problema, proferindo decisões que, fundadas nas tradicionais abordagens à brasileira do direito (por vezes afastada da realidade), protegem-se na esteira de um discurso dogmático consagrado, tal como a supremacia e a indisponibilidade do interesse público ou que a utilização de terrenos públicos não gera qualquer direito possessório, mas mera detenção. Esse tipo de abordagem, especialmente nos casos de maior complexidade, gera inúmeras vezes decisões conflitantes e a consequente descrença e desconfiança dos cidadãos para com a capacidade da Justiça para resolver os problemas enfrentados no campo da realidade.

Nota-se que as rápidas e contínuas mudanças das estruturas sociais apresentam novos problemas para a teoria tradicional do direito. A dinâmica das relações sociais revela processos complexos e acelerados dessas transformações, que se mostram profundas e marcantes, constituindo-se uma das razões para a crise atual do juspositivismo. Isso permite asseverar que, para a resolução de determinados problemas, a compreensão do direito como algo autômato voltado à regulação estática de fenômenos sociais encontra-se superada, de modo que se deve vislumbrá-lo como um mecanismo dinâmico direcionado à solução de problemas concretos, especialmente para a sustentação de políticas públicas que buscam tal fim.

A formação da Comunidade do Horto no que se refere à sua composição, às suas próprias tradições e relações com o espaço que habitam, a maneira de apossamento 
das terras - ora com consentimento do poder público ora com divisão e disputa por espaços, o tempo de existência das primeiras vilas no local (que remonta ao período oitocentesco da história brasileira), a importância cultural e social do parque do Jardim Botânico para a cidade e para o País, os discursos em torno do tombamento, do direito à moradia, do direito ambiental, da expansão da pesquisa botânica e, especialmente, as práticas atuais de gestão do patrimônio imobiliário federal, para enumerar apenas alguns fatores, oferecem uma multifacetada gama de interesses políticos em torno da questão que dificultam sobremaneira o alcance de uma solução justa para o caso, ainda mais se consideradas as dificuldades instrumentais enfrentadas pelos tribunais e instituições públicas brasileiras.

Não bastasse, a atuação desarticulada dos diversos atores institucionais nos processos judiciais e administrativos contribui para a insegurança da comunidade, leva a um desenho disforme e contraditório das políticas de gestão e administração da área envolvida, estabelece regimes e entendimentos jurídicos diferenciados aplicáveis a cada caso, e desconsidera a gestão contextual do problema, tudo em franca contribuição para com o acirramento dos conflitos existentes no local.

Deve-se notar que a instauração formal de Câmara de Conciliação e Arbitragem da Administração Pública Federal para dirimir os conflitos existentes é passo importante na busca de um norte para resolver os problemas enfrentados no local. Ela permite que representantes de diversos órgãos públicos sentem à mesma mesa, na condição de agentes pensadores de políticas públicas, para o debate e o fomento de soluções para cada problema posto ao seu crivo. Tais agentes são sempre acompanhados de um advogado público, que funciona como uma espécie de assessor quanto à verificação de viabilidade, alternativas, segurança e consequências jurídicas para essas decisões de caráter político.

$\mathrm{Na}$ fase atual do problema, a administração pública tem a oportunidade de aproveitar os trabalhos desenvolvidos no âmbito da CCAF, que deve coordenar os órgãos envolvidos, de forma participativa, visando à real mensuração da extensão do problema, que passa pela correta identificação da área pertencente à União com a consequente matrícula do imóvel em seu nome no competente cartório de registro imobiliário, a formalização contratual da utilização dessa área pelo IJBRJ, as reais necessidades de expansão de equipamentos e edificações do Jardim Botânico para o fomento de suas atividades finalísticas, a identificação das áreas de risco onde não é possível o estabelecimento de habitações, a individualização dos moradores, considerando-se, fundamentalmente, o tempo de moradia, os laços com a terra, a faixa de renda e o interesse em permanecer ou deixar o local, mediante eventual contraprestação financeira, assim como a possibilidade de outorga de títulos formais pela utilização de área da União nas áreas eventualmente não albergadas pelo tombamento, visando à promoção de confiança da comunidade para com os atos estatais. 
Contudo, é preciso alertar que a longa espera enfrentada para a resolução dos conflitos no Jardim que, além de introduzir tensões no seio da sociedade carioca, tem contribuído sobremaneira para o aumento exponencial do número de ocupações nos últimos trinta anos. Por isso, deve ser exigida maior agilidade na condução dos trabalhos que visam buscar solução para o local. É preciso, ainda, considerar que a suspensão dos processos judiciais pode ser, a qualquer momento, individualmente revogada nas inúmeras ações possessórias sobre o caso, o que impactaria negativamente os trabalhos realizados em âmbito administrativo, mais uma razão pela qual se torna premente conferir maior agilidade na apresentação de plano de trabalho apto a arrefecer a questão, o que permitiria relativa tranquilidade na execução da política de gestão para a área.

Além das definições quanto aos limites do tombamento e das áreas necessárias à expansão da pesquisa botânica até hoje não perpetradas, no nosso sentir, a individualização no trato dos casos existentes, a criação de mecanismos e incentivos econômicos para a desocupação voluntária do local, a proposição de realocação dos moradores em outras áreas e, fundamentalmente, a atuação concertada dos órgãos da administração pública federal (sob o comando da chefia do Poder Executivo e sob a coordenação da Advocacia-Geral da União) configuram-se inputs inafastáveis para o desenho de solução mais próxima daquilo que pensamos como justiça.

Trata-se, pois, de problema social para o qual se deve buscar a construção de uma política que esteja voltada à gestão participativa, que tenha seus nortes e diretrizes legitimamente definidas pelas autoridades competentes, em consonância com o novo paradigma de gestão dos imóveis da União, sem que se afaste do respeito à preservação ambiental e dos estudos botânicos, de forma que o poder público possibilite a solução definitiva dos problemas enfrentados pela Comunidade do Horto e pelo próprio Jardim Botânico, que coexistem há mais de duzentos anos no local.

: ARTIGO APROVAdo (02/12/2012) : RECEBIDO EM 31/07/2012

NOTAS

1 O autor deste artigo é aluno regular do Programa de Mestrado e Doutorado em Direito do Centro Universitário de Brasília (UniCEUB), linha de pesquisa: Direito e Políticas Públicas.

2 Ambos os pontos, dentre outros, anunciados na ementa da disciplina Bases Sociais do Estado Contemporâneo, oferecida na grade regular, ministrada pelo Prof. Dr. Luiz Eduardo de Lacerda Abreu. 
3 Segundo Alasdair MacIntyre: "Emovitismo é a doutrina segundo a qual todos os juízos valorativos e, mais especificamente, todos os juízos morais não passam de expressões de preferência, expressões de sentimento ou atitudes, na medida que são de caráter moral ou valorativo" (MacIntyre, 2004, p. 30).

4 Rawls, 2008.

5 Freitas Filho, 2003.

6 De modo breve, pode-se pensá-lo como sendo a abordagem científica ao direito (i) comprometida com a construção e utilização de um método específico capaz de fornecer descrições neutras sobre o fenômeno jurídico; e (ii) que concebe o direito como um sistema de normas produzidas pelos órgãos oficiais do Estado (cf. Cintra, 2011).

7 Faria, 1988, p. 22.

8 As noções de paradigma empregadas pelo autor são aquelas delineadas em Thomas Khun, 1996.

9 Essa pluralidade de discursos, todos consagrados no campo político-jurídico, sejam conflitantes ou aparentemente conflitantes, é identificada em Rawls por Abreu (2006): "Rawls introduz a distinção entre concepção política e doutrinas abrangentes (comprehensive doctrines) que vai basear tanto a formulação do problema quanto a sua solução. Por 'concepção' ele entende uma 'concepção política e suas partes, como o conceito de pessoa como cidadão'; por 'doutrina', as 'perspectivas abrangentes de todos os tipos' (Rawls, 2005, p. xxxv, 441), isto é, doutrinas que incluíssem não apenas a dimensão político-constitucional, mas também ideias que perpassassem outras esferas da vida social, tais como concepções religiosas, filosóficas, morais, científicas, etc. Assim, 'uma vez que a questão é colocada [a distinção entre concepção política e doutrina abrangente], fica claro - acredito - que o texto [de Uma teoria] percebe a justiça como equidade e o utilitarismo como doutrinas abrangentes ou parcialmente abrangentes' (Rawls, 2005, p. xvi). Daí, a solução de Rawls é a transformação daquilo que, em uma teoria da justiça, é uma doutrina abrangente, numa concepção puramente política e, portanto, independente (freestanding); em outras palavras, uma concepção que não está fixa a nenhuma doutrina abrangente e pode ser subscrita por uma pluralidade de doutrinas razoáveis - fato que ele chama de 'consenso sobreposto' (overlapping consensus). A partir daí, a justiça como equidade poderia ser considerada como uma concepção puramente política e, portanto, limitada à formulação da estrutura básica da sociedade, aos valores propriamente políticos" (Abreu, 2006, p. 157).

10 Medauar (2003) parte para uma definição valorativa: “a palavra público significa que o valor ético no padrão do interesse público se aplica a todo membro da comunidade política: é um valor que se deve distinguir de algo que é vantajoso para uma pessoa e desvantajoso para outra. A palavra interesse indica o sentido estimativo do padrão; refere-se a algo em que deveríamos estar 'interessados', muito embora possamos não estar. Por isso, dizer que uma ação é do interesse público significa julgá-la de acordo com uma situação política que é benéfica para todo mundo” (Medauar, 2003, p. 37).

11 Ibid., p. 48

12 Ari Sundfeld, 2008

13 Câmara de Conciliação e Arbitragem da Administração Federal - CCAF, órgão da Consultoria-Geral da União, foi criada pelo Ato Regimental n. 5, de 27 de setembro de 2007, e tem sua forma de atuação regulamentada pela Portaria AGU n. 1.281, de 27 de setembro de 2007, cujo objetivo principal é evitar litígios entre órgãos e entidades da Administração Federal. Com a edição da Portaria AGU n. 1.099, de 28 de julho de 2008, as controvérsias de natureza jurídica entre a Administração Pública Federal e a Administração Pública dos Estados ou do Distrito Federal também são matérias de competência da CCAF (cf. texto constante da Cartilha da Câmara de Conciliação e Arbitragem). Disponível em: <http://www.agu.gov.br/sistemas/site/PaginasInternas/download/cartilhas/Cartilha_CCAF_03_02_09.pdf>. Acesso em: 7 jan. 2012.

14 Extraído do processo administrativo n. 00405.008207/2010-50.

15 Nesse sentido, o diálogo baseia-se na capacidade de as soluções corresponderem aos julgamentos intuitivos ou, como ele mesmo afirma: "podemos observar se a aplicação destes princípios [escolhidos na posição inicial] nos levaria a fazer, a respeito da estrutura básica da sociedade, os mesmos julgamentos que agora fazemos intuitivamente e nos quais depositamos maior confiança (...) Podemos então avaliar uma interpretação da situação inicial pela capacidade de seus princípios em 
atender às nossas convicções mais profundas e oferecer orientação onde se fizer necessário” (Rawls, 2002, p. 22). Ora, justamente esse diálogo entre as formulações da situação inicial e os julgamentos intuitivos do leitor fornece um critério crítico auto-referenciado, que Rawls (2002, p. 23) formula da seguinte maneira: "às vezes alterando as condições das circunstâncias em que se deve obter o acordo original, outras vezes modificando nossos juízos e conformando-o com os novos princípios, suponho que acabaremos encontrando a configuração da situação inicial que ao mesmo tempo expresse pressuposições razoáveis e produza princípios que combinem com nossas convicções devidamente apuradas e ajustadas. A esse estado de coisas eu me refiro como equilíbrio ponderado [no original, reflective equilibrium]. Trata-se de um equilíbrio porque finalmente nossos princípios e opiniões coincidem; e é reflexivo porque sabemos com quais princípios nossos julgamentos se conforma e conhecemos as premissas das quais derivam. Neste momento tudo está em ordem (Abreu, op. cit. p. 153).

16 Abreu formula da seguinte maneira: "numa sociedade real, os argumentos dos indivíduos sobre o que seria justo estão efetivamente influenciados pelas suas respectivas posições sociais, riqueza, valores religiosos, crenças pessoais, as escolhas éticas, a história pessoal, etc. Mais ainda, esses condicionantes representam posições sociais assimétricas, quer dizer, elas incorporam não apenas diferenças individuais, mas sobretudo desigualdades. Essas desigualdades, por sua vez, não são apenas o resultado do esforço pessoal numa situação de igualdade de oportunidades, mas são construídas e perpetuadas socialmente. Em outras palavras, os argumentos sobre o que seria justo numa sociedade real potencialmente - e na minha opinião de fato - refletem, nalguma medida, as injustiças da própria sociedade. Como alguém poderia depositar confiança nos juízos construídos dessa forma? Nesse sentido, a posição original, o véu da ignorância, a suposição dos indivíduos racionais e a questão de qual seria a decisão mais racional numa situação assim delineada servem como instrumentos analíticos que permitem formular uma conjectura (o termo é do próprio Rawls, 1995, p. 139), conjectura que pode basear os argumentos que utilizamos em situações discursivas reais. Teríamos boas razões para depositar confiança nesses argumentos, porque: (1) eles representam juízos que seriam o resultado de uma situação equitativa; e (2) podem ser criticados tanto em relação ao seu procedimento (se o método foi bem empregado) como, principalmente, (3) em relação ao seu conteúdo" (Abreu, op. cit. p. 155).

17 MacIntyre, op. cit., 1981

18 “O significado que darei à 'prática' será o de qualquer forma coerente e complexa de atividade humana cooperativa, socialmente estabelecida, por meio da qual os bens internos a essa forma de atividade são realizados durante a tentativa de alcançar os padrões de excelência apropriados para tal forma de atividade, e parcialmente dela definidores, tendo como consequência a ampliação sistemática dos poderes humanos para alcançar tal excelência, e dos conceitos humanos dos fins e dos bens envolvidos." (Ibid., p. 316).

19 "Naturalmente não posso negar, e na verdade a minha tese exige, que a linguagem e as aparências da moralidade persistam, embora a substância integral da moralidade tenha se fragmentado muito e, assim, tenha sido, em parte, destruída. Por isso não há incoerência quando falo, como farei adiante, de posturas e argumentos morais contemporâneos. Simplesmente faço ao presente a cortesia de usar seu próprio vocabulário para falar dele.” (Ibid., p. 20) .

20 Liu, 2008-2009, p. 203-270.

21 Criada pela Lei 10.316, de 6 de dezembro de 2001, cabe à autarquia, fundamentalmente, "promover, realizar e divulgar o ensino e as pesquisas técnico-científicas sobre os recursos florísticos do Brasil, visando o conhecimento e a conservação da biodiversidade, bem como manter as coleções científicas sob sua responsabilidade”.

22 "A história da região, assim como de toda a zona sul da cidade do Rio de Janeiro, está associada a do Engenho de Nossa Senhora da Conceição da Lagoa, um dos mais antigos engenhos de açúcar da cidade, fundado por Diogo de Amorim Soares, em 1596. Em 1660, a propriedade foi adquirida por Rodrigo de Freitas Mello e Castro, que mais tarde passou para seus filhos e posteriormente para seus netos. No final do século 18 , as terras do engenho compreendiam todas a área atualmente ocupada pelos bairros do Jardim Botânico, Gávea Leblon, Ipanema, Arpoador, Lagoa, parte do Humaitá e grande parte do Parque Nacional da Tijuca. Além do engenho de açúcar, localizado na área onde atualmente se situa o Jardim Botânico, existiam ainda dentro desta grande propriedade 59 chácaras arrendadas a terceiros" (Serviço Público Federal, Ministério da Cultura, Iphan. Laudo de Vistoria - Bens Imóveis Tombados, Brasil). Extraído do processo $\mathrm{n}$. 90.0049294-7, em trâmite na $3^{\text {a }}$ Vara Federal do Rio de Janeiro, fls. 293-318.

23 Jardim Botânico do Rio de Janeiro: 1808-2008, [organizado por] Instituto de Pesquisas Jardim Botânico do Rio de Janeiro, 2008, p. 27. Frise-se que a Fábrica de Pólvora e a Fundição de Artilharia tiveram suas sedes transferidas para Petrópolis em 1826, região serrana do Estado do Rio de Janeiro. 
24 cf. Bello, Enzo. Artigo publicado nos Anais do XVII Congresso Nacional do CONPENDI, Brasília, nov. 2008.

25 Jardim Botânico do Rio de Janeiro: 1808-2008, op. cit., p. 173-174.

26 No final do século 19, "as realizações mais marcantes, de impacto direto no uso público do Jardim, foram: as alterações no regulamento Policial; a publicação do Primeiro Guia para o visitante, com histórico, regulamento policial e relação de todas as plantas com sua localização no Jardim; a organização paisagística, que criou canteiros, aleias, sinalização para orientar o público e identificação das espécies botânicas; criação do Museu Kuhlmann; a criação da Biblioteca Barbosa Rodrigues, do Herbário e de Laboratórios; a instalação de setores destinados a estudos botânicos para possibilitar o atendimento às comunidades científicas; realização de Exposições Botânicas e Históricas; a instalação do Parque Infantil; a realização de cursos; criação de setores destinados à Educação para o Meio Ambiente e a Responsabilidade Social, além de ações e eventos que aproximaram a iniciativa privada da Instituição, em parcerias que possibilitam apoiar diversos de seus projetos e a manutenção de seu acervo físico". (in Jardim Botânico do Rio de Janeiro: 1808-2008, op. cit., p. 174.

27 A política habitacional era baseada na casa própria, fundada em política de financiamento levada a efeito pelo Banco Nacional de Habitação e apoiada por captação de recursos específicos e subsidiados pelo governo, inclusive FGTS, conforme se percebe das diretrizes constantes da Lei n. 4.380, de 21 de agosto de 1964. Disponível em: <http://www.planalto.gov.br/ccivil_03/leis/L4380.htm>

28 Roberto Burle Marx (1909-1994) foi um artista plástico, renomado internacionalmente ao exercer a profissão de arquiteto-paisagista. Trabalhou como colaborador do Iphan nas décadas de 1960 e1970, tendo proferido os seguintes dizeres sobre a possibilidade, aventada no fim da década de 1960, de cessão de área do Horto Florestal para o Banco Nacional de Habitação desenvolver projeto imobiliário: "O Jardim Botânico tem sido retalhado e diminuído de sua área, através do constante uso de manobra sorrateira e hábil (...). O Horto é uma gleba de 83 hectares, o prolongamento natural do Jardim Botânico (...). Todas as atividades técnicas a que se propunha nunca foram interrompidas até a presente data (1969). Não é admissível que uma parte seja desmembrada e cedida ao Banco Nacional de Habitação, que apenas vê o problema habitacional e nega completamente a validade cultural dessa instituição, onde um grande número de botânicos, de valor nacional e internacional, trabalhou e produziu para a ciência. Se consumar a cessão da área, veremos o Jardim Botânico transformado em quintal dessas habitações, como muito bem disse o eminente colega Pedro Calmon. Por estas circunstâncias, é que se contraindica a construção de blocos residenciais, com finalidade imobiliária, nesta zona. (...) Em face do exposto, a oferta de qualquer área do Horto Florestal, em parcelas mínimas ou no todo (83 hectares), constitui uma violação das instituições culturais e da história, o mesmo se afirmando ao Jardim Botânico que, com o Horto, se constitui num todo indivisível, na totalidade da área de $1.370 .000 \mathrm{~m}^{2}$ ”. Extraído do processo administrativo $\mathrm{n}$. 00405.008207/2010-50, fl. 380 .

29 Informações extraídas do processo administrativo no 00405.008207/2010-50, fl. 379, verbis: "Processo de Tombamento $\mathrm{n}^{\circ}$ 101-T-38 e 157-T. Jardim Botânico do Rio de Janeiro, inclusive o Pórtico da Academia de Belas Artes, Portão da Antiga Fábrica de Pólvora e o Antigo Aqueduto da Levada - Inscrição n ${ }^{\circ} 02 /$ fls. 02, datada de 30/05/38, no Livro Arqueológico, Etnográfico e Paisagístico; Processo de Tombamento ${ }^{\circ}$ 762-T-65. Parque Nacional da Tijuca e Remanescentes Florestais da Mata Atlântica situados acima da cota de 100 metros do nível médio do mar dentro da área do Jardim Botânico do Rio de Janeiro, parte integrante do JBRJ - Inscrição n ${ }^{\circ}$ 42/fls. 10, datada de 27/04/67, no Livro Arqueológico, Etnográfico e Paisagístico; Processo de Tombamento n ${ }^{\circ}$ 633-T-73. Conjunto Paisagístico do Antigo Horto Florestal - Inscrição datada de 17/12/73 no Livro Arqueológico, Etnográfico e Paisagístico".

30 Portaria Interministerial n. 360-A, de 27 de dezembro de 2004 (DOU, 28/01/2005). "Os MINISTROS DE ESTADO DO PLANEJAMENTO, ORÇAMENTOE GESTÃO e DO MEIO AMBIENTE, no uso de suas atribuições legais e tendo em vista o disposto na Lei n.10.683, de 28 de maio de 2003, e no Acórdão n. 1.028/2004 - TCU - Plenário, publicado no Diário Oficial da União de 5 de agosto de 2004, Seção 1, páginas 80 e 81 , resolvem: Art. $1^{\circ}$ Instituir Comissão Interministerial com a finalidade de promover estudos e propor soluções que possibilitem à Secretaria do Patrimônio da União-SPU a regularização da cessão do imóvel de domínio da União, constituído pelo Jardim Botânico do Rio de Janeiro, ao Instituto de Pesquisas Jardim Botânico do Rio de Janeiro-JBRJ, autarquia vinculada ao Ministério do Meio Ambiente".

31 Relatório da Comissão Interministerial, de 22 de fevereiro de 2007 (extraído do processo n. 90.0049294-7, em trâmite na $3^{\text {a }}$ Vara Federal do Rio de Janeiro, p. 293/318).

32 Os dados absolutos indicados constam do Relatório de Comissão Interministerial, de fevereiro de 2007 (extraído do processo n. 90.0049294-7, em trâmite na $3^{\mathrm{a}}$ Vara Federal do Rio de Janeiro, p. 293-318). 
33 Cf. Portaria da Ministra de Estado do Planejamento, Orçamento e Gestão n. 357, DOU, 16.09.2011.

34 Lei n. 9.636, de 15 de maio de 1998, DOU,18/05/1998 (relatório de internet). Disponível em: <http://www.planalto.gov.br/ccivil_03/Leis/L9636.htm>.

35 Constituição Federal, art. $5^{\circ}$, inciso XXIII.

36 Disponível em: <http://patrimoniodetodos.gov.br/politica-nacional-de-gestao-do-patrimonio-da-uniao-pngpu>.

37 Disponível em: <http://patrimoniodetodos.gov.br/politica-nacional-de-gestao-do-patrimonio-da-uniao-pngpu>

38 “Destaca-se, assim, na gestão do Patrimônio Imobiliário da União, a efetivação de algumas ações estruturantes, como o apoio à reforma agrária, o reconhecimento de comunidades remanescentes de quilombos e sua fixação nas terras de seus antepassados, a demarcação das terras indígenas, o reconhecimento de direitos das comunidades tradicionais e extrativistas, a destinação de imóveis da União para o Programa de Aceleração do Crescimento (PAC), para o Programa Minha Casa Minha Vida e para demais programas de urbanização de assentamentos precários e de provisão habitacional do Ministério das Cidades e, ainda, a regularização fundiária em terras da União na Amazônia. Todas elas, independentemente do modelo estrutural em que são alocadas dentro da forma de condução da PNGPU, refletem necessariamente os mesmos princípios ideológicos que constituem a base de sustentação da política de gestão pública que orientou a formulação dos programas de governo: o Patrimônio da União a serviço do Brasil, a serviço de todos os brasileiros, na construção de um país de todos." Secretaria do Patrimônio da União, Ministério do Planejamento, Orçamento e Gestão: Balanço de Gestão 2003-2010, p. 10. Secretaria do Patrimônio da União, Ministério do Planejamento, Orçamento e Gestão: Balanço de Gestão 2003-2010 (relatório de internet). Disponível em: <http://patrimoniodetodos.gov.br/politica-nacional-degestao-do-patrimonio-da-uniao-pngpu/balanco-de-gestao-2003-a-2010>.

39 Disponível em: <http://patrimoniodetodos.gov.br/pastaarquivo.2009-07-09.3759851862/ BalancodeGestaoSPU31jan11.pdf>, p. 51 .

40 Disponível em: <http://patrimoniodetodos.gov.br/pastaarquivo.2009-07-09.3759851862/ BalancodeGestaoSPU31jan11.pdf>, p. 75 .

41 Dados obtidos do "Balanço de Gestão 2003-2010", op. cit., p. 68-72.

42 Referido dispositivo está inserido no Capítulo II, Título VII, referente à Política Urbana nacional. À sua redação: “Art. 183. Aquele que possuir como sua área urbana de até duzentos e cinquenta metros quadrados, por cinco anos, ininterruptamente e sem oposição, utilizando-a para sua moradia ou de sua família, adquirir-lhe-á o domínio, desde que não seja proprietário de outro imóvel urbano ou rural. $\S 1^{\circ}$ - O título de domínio e a concessão de uso serão conferidos ao homem ou à mulher, ou a ambos, independentemente do estado civil; $\S 2^{\circ}$ - Esse direito não será reconhecido ao mesmo possuidor mais de uma vez; $\S 3^{\circ}$ - Os imóveis públicos não serão adquiridos por usucapião”.

43 Veja-se da redação do art. $1^{\circ}$, MP 2.220/2001, que expõe as condições para a obtenção da CUEM: "Aquele que, até 30 de junho de 2001, possuiu como seu, por cinco anos, ininterruptamente e sem oposição, até duzentos e cinquenta metros quadrados de imóvel público situado em área urbana, utilizando-o para sua moradia ou de sua família, tem o direito à concessão de uso especial para fins de moradia em relação ao bem objeto da posse, desde que não seja proprietário ou concessionário, a qualquer título, de outro imóvel urbano ou rural”.

44 A CUEM já havia constado do projeto de lei que culminou na edição da Lei n. 10.257, de julho de 2001, conhecida como "Estatuto da Cidade". Na oportunidade, toda a Seção VI (artigos 15 a 20) foi vetada pelo Presidente da República que, em sua mensagem de veto, apresar de ter reconhecido que "o instituto jurídico da concessão de uso especial para fins de moradia em áreas públicas é um importante instrumento para propiciar segurança da posse fundamento do direito à moradia - a milhões de moradores de favelas e loteamentos irregulares", e assinalou "algumas imprecisões do projeto de lei trazem, no entanto, riscos à aplicação desse instrumento inovador, contrariando o interesse público". Ao final, a mensagem asseverou: "em reconhecimento à importância e validade do instituto da concessão de uso especial para fins de moradia, o Poder Executivo submeterá sem demora ao Congresso Nacional um texto normativo que preencha essa lacuna, buscando sanar as imprecisões apontadas", o que resultou, menos de dois meses depois, na publicação da Medida Provisória n. 2.220, em setembro de 2001. Mensagem de Veto n. 730. Disponível em: <http://www.planalto.gov.br/ccivil_03/leis/Mensagem_Veto/2001/Mv730-01.htm>. 
45 O Ministério das Cidades foi instituído em $1^{\circ}$ de janeiro de 2003, através da Medida Provisória n. 103, depois convertida na Lei n. 10.683, de 28 de maio do mesmo ano. O Decreto n. 4665, de 3 de abril de 2003, aprova a Estrutura Regimental do Ministério, incluindo a Secretaria Nacional de Programas Urbanos, que, com a edição do Decreto 7.618, de 2011, passou a se chamar Secretaria Nacional de Acessibilidade e Programas Urbanos. Ministério das Cidades, nov. /2010: Apresentação de dados, balanço e avaliação da política. Disponível em: $<$ http: / / www.abconline.org.br/Downloads/Minist\%C3\%A9rio\%20das\%20Cidades $\% 20=$ apresenta $\%$ C3\%A7\%C3\%A3o\%20do\% $20 \mathrm{dia} \% 2016 \% 20 \mathrm{de} \% 20$ novembro.pdf>.

46 À redação do dispositivo: "a ampliação do acesso à terra urbanizada pela população de baixa renda, com prioridade para sua permanência na área ocupada, assegurados o nível adequado de habitabilidade e a melhoria das condições de sustentabilidade urbanística, social e ambiental; articulação com as políticas setoriais de habitação, de meio ambiente, de saneamento básico e de mobilidade urbana, nos diferentes níveis de governo e com as iniciativas públicas e privadas, voltadas à integração social e à geração de emprego e renda; participação dos interessados em todas as etapas do processo de regularização; estímulo à resolução extrajudicial de conflitos; e concessão do título preferencialmente para a mulher".

47 United Nations. Cities and Climate Change: Global Report on Human Settlements 2011. Disponível em: <http://www.unhabitat.org/downloads/docs/GRHS2011/GRHS.2011.Abridged.English.pdf>.

48 Vieira, 2008. Disponível em: <http//:www.jbrj.gov.br/materias/20_07_2005.htm>. Acesso em: 4 fev 2012.

49 Tribunal de Contas da União. Acórdão n. 2380/2012 - Plenário. Processo: TC 030.186/2010-2. Disponível em: <http://portal2.tcu.gov.br/portal/page/portal/TCU/imprensa/noticias/noticias_arquivos/030.186-20102\%20Jardim\%20Bot\%C3\%A2nico.pdf>. Acesso em: 22 set. 2012.

50 O texto do Relatório de Levantamento do TCU apresenta a seguinte referência: Mello, 2005, p. 41. (apud Martinez, Direitos e garantias individuais e homogêneas da inclusão social, in R. Trib. Reg. Trab. 14 ${ }^{a}$ Reg., Porto Velho, v. 6, n. 2, p. 722-723, jul./dez. 2010). Disponível em: <http://www.trt14.jus.br/Documentos/Revista_TRT14_2010_n2.pdf>. Acesso em: 10 ago. 2011.

\section{REFERÊNCIAS BIBLIOGRÁFICAS}

ABREU, Luiz Eduardo de Lacerda. Qual o sentido de Rawls para nós? Revista de Informação Legislativa. Brasília, a. 43, n. 172 .

ALEXANDER, Larry, and Emily Sherwin. Deceptive Nature of Rules. University of Pennsylvania Law Review 142, n. 4 (1993-1994): 1191-226.

BELLO, Enzo. Artigo publicado nos Anais do XVII Congresso Nacional do CONPENDI, Brasília, nov. 2008. BOURDIEU, Pierre. O poder simbólico. Lisboa: Difel, 1989.

. Esboço de teoria da prática. In: Pierre Bourdieu. (Org.) São Paulo: Ática, 1983.

O campo científico. In: Pierre Bourdieu (Org.) São Paulo: Ática, 1983.

BUCCI, Maria Paula Dallari. (Org.) Políticas públicas: reflexões sobre o conceito jurídico. São Paulo: Saraiva, 2006. CAMPILONGO, Celso; FARIA, José Eduardo. A sociologia jurídica no Brasil. Porto Alegre: Sérgio Fabris, 1991. FARIA, José Eduardo. A crise do direito numa sociedade em mudança. Brasília: UnB, 1988.

FERREIRA et al. Uma experiência de desenvolvimento metodológico para avaliação de programas: O modelo lógico do programa segundo tempo, TD 1369, Ipea, 2009.

FREITAS FILHO, Roberto. Crise do direito e juspositivismo. Brasília: Jurídica, 2003.

GUIMARÃES, Guilherme F. A. Cintra. Avvocatura dello Stato, amministrazione pubblica e democrazia: il ruolo della consulenza legale nella formulazione ed esecuzione delle politiche pubbliche. Rassegna Avvocatura dello Stato. Roma, Anno LXIII, n. 1, Gennaio-Marzo 2011.

JARDIM BOTÂNICO do Rio de Janeiro: 1808-2008. Organizado por Instituto de Pesquisas Jardim Botânico do Rio de Janeiro, 2008.

KELSEN, Hans. Teoria geral do direito e do Estado. Trad. por Luíz Carlos Borges. São Paulo: Martins Fontes, 2000. Teoria pura do direito. São Paulo: Martins Fontes, 2006. 
KUHN, Thomas. A estrutura das revoluções científicas. São Paulo: Perspectiva, 1996.

LATOUR et al. A vida de laboratório - a produção de fatos científicos. Rio de Janeiro: Ed. Relume Dumará, 1997. LIU, Goodwin. Rethinking Constitutional Welfare Rights. Stanford Law Review 61, n. 2 (2008-2009).

LOPES, Jose Reinaldo de Lima. Cidadania e propriedade: perspectiva histórica do direito a moradia. Revista de Direito Alternativo, n. 2, p. 114-136, 1993.

MACINTYRE, Alasdair. Depois da virtude. Trad. por Jussara Simões. 3. ed. Bauru: Edusc, 2004.

MEDAUAR, Odete. O direito administrativo em evolução. 2. ed. São Paulo: Revista dos Tribunais, 2003.

RAWLS, John. Uma teoria da justiça. São Paulo: Martins Fontes, 2008.

SARAVIA, Enrique. Introdução à teoria da política pública. In: Enrique Saravia e Elisabete Ferrarezi. (Orgs.)

Políticas públicas, coletânea. Vol. II. Brasília: Enap, 2006.

SANDEL, Michael J. Liberalism and the Limits of Justice. Cambridge: Cambridge University Press, 1982.

SELZNICK, Philip. The Idea of a Communitarian Morality. California Law Review, 75, n. 1 (1987): 445-64

SUNDFELD, Carlos Ari. O Direito Administrativo entre os clips e os negócios. In: Alexandre Aragão; Floriano de Azevedo Marques Neto. (Orgs.) Direito administrativo e seus novos paradigmas. Belo Horizonte: Fórum, 2008.

TAYLOR, Charles. Atomism. In: Shlomo Avineri; Avner De-Shalit. (Orgs.) Communitarianism and Individualism. Oxford/Nova York: Oxford University Press, 1992.

VIANA, Ana Luiza. Abordagens metodológicas em políticas públicas. Revista de Administração Pública, v. 30, n. 2, p. 5-43, mar. /abr. 1996.

VIEIRA JUNIOR, Ronaldo Jorge Araujo. A advocacia pública federal e a sustentabilidade jurídico-constitucional das políticas públicas: dimensões, obstáculos e oportunidades na atuação da Advocacia-Geral da União. In:

GUEDES, Jefferson Carús Guedes; Luciane Moessa de Souza. (Org.) Advocacia de Estado: questões institucionais para a construção de um Estado de Justiça. Belo Horizonte: Fórum, 2009.

WALZER, Michael. Spheres of Justice: A Defense of Pluralism and Equality. Nova York: Basic Books, 1983.

Armando Miranda Filho

CCSW 04, Lote 01, b. A, apto. 208 $70.680-450$ Brasília - DF - Brasil armando.miranda.filholagmail.com
Aluno regular do Programa de Mestrado e Doutorado em Direito e Políticas Públicas do UniCEUB 